\title{
Raw material exploitation strategies on the flint mining site of Spiennes (Hainaut, Belgium)
}

\author{
Hélène Collet ${ }^{1}$, Philippe Lavachery ${ }^{2}$, Michel Woodbury ${ }^{1}$ \\ 1. Service public de Wallonie, Service de l’Archéologie de la Direction du Hainaut I, 52 rue d’Harmignies, 7032 \\ Spiennes, Belgium. Email: Collet: helene.collet@spw.wallonie.be; \\ Woodbury: michel.woodbury@spw.wallonie.be \\ 2. Société de Recherche préhistorique en Hainaut, 9 rue Gontrand Bachy, 7032 Spiennes, Belgium. \\ Email: philippe.lavachery@hotmail.com
}

\begin{abstract}
:
The flint mines of Spiennes (Hainaut Province, Belgium) are among the most important mining sites in Europe as evidenced by the huge extension of the site and its very long duration of occupation, probably covering a period between 4350 and 2300 BCE. What explains such a spectacular achievement? The paper first explores the geological constraints but also the social and material conditions that made possible such a continuity of mining activities. The site of Spiennes offers both extremely rich flint resources and a specific geographical configuration that made the discovery and the exploitation of the deposit relatively easy in the Neolithic. The paper next focuses on deducing the mining strategies implemented to extract good quality raw materials on basis of both stratigraphical evidence and the flint productions in direct relation with the mines. The mining strategies variability from a synchronic and a diachronic point of view as well as the knapping techniques implemented will be analysed. These are then put into perspective with what is known of the social context in which the mining activities took place. At the turn of the 5th and the 4th millennium BCE a permanent settlement was built near the mining site. As the Michelsberg populations who exploited the mines in Spiennes were first and foremost farmers, this leads us to propose a tentative hypothesis about the seasonality of the mining activities. Living close to a hugely rich flint deposit, these farmers were able to develop sometimes complex mining techniques to reach specific seams, deemed adequate for the production of standardised axeheads and blades. Century-old traditions, group specialisation in mining and knapping and close social control of flint resources allowed the mines to dominate the raw material supply of the Mons Basin for centuries.
\end{abstract}

Keywords: Neolithic; raw material; flint; mining techniques; underground mining; axeheads; blades

\section{Résumé}

Les minières de Spiennes (Province de Hainaut, Belgique) figurent parmi les plus importants sites miniers d'Europe comme le montrent l'étendue du site et sa longue durée d'occupation qui couvre une période comprise probablement entre 4350 et 2300 ans avant notre ère. Qu'est ce qui a rendu cet exploit possible? Notre article explore tout d'abord les contraintes géologiques mais

Published by the School of History, Classics and Archaeology, University of Edinburgh ISSN: 2055-0472. URL: http://journals.ed.ac.uk/lithicstudies/

This work is licensed under a Creative Commons Attribution 2.5 UK: Scotland License. 
également le contexte matériel et social qui a rendu possible une telle continuité des activités minières. Le site de Spiennes possède à la fois des gisements de silex extrêmement riches et une configuration géologique spécifique qui a rendu la découverte et l'exploitation de ces ressources relativement aisées au Néolithique. L'article se concentre ensuite sur l'identification des stratégies minières mises en œuvre pour extraire une matière première de bonne qualité en se basant à la fois sur les preuves stratigraphiques et sur les productions de silex en relation directe avec les minières. Ces stratégies minières sont analysées d'un point de vue à la fois synchronique et diachronique ainsi que les techniques de taille et de débitage mises en œuvre. Celles-ci sont mises en perspectives avec ce que l'on sait du contexte social dans lequel ces activités minières se sont développées. Au tournant des $5^{\text {ème }}$ et $4^{\text {ème }}$ millénaires un habitat permanent est installé à proximité du site minier. Comme les populations Michelsberg étaient avant tout des agriculteurs et éleveurs, cela nous amène à proposer une hypothèse préliminaire sur la saisonnalité des activités minières. Vivant tout près de dépôts de silex extrêmement riches, ces agriculteurs ont été capables de développer des techniques minières parfois complexes afin d'atteindre des bancs spécifiques considérés comme adéquats pour la production de haches et de lames standardisées. Des traditions séculaires, une spécialisation de certains individus dans le groupe et un contrôle social strict des ressources en silex a permis aux mines de dominer l'approvisionnement en matières première du bassin de Mons pendant des siècles.

Mots-clefs: Néolithique; matière première; silex; techniques minières; exploitation souterraine; lames de hache; lames

\section{Introduction}

The Neolithic flint mines of Spiennes are located in the west of Middle Belgium on the southern edge of the Mons Basin, in the Hainaut Province (Figure 1). The region was a privileged area for the procurement of good quality flint since time immemorial. As early as the Lower and Middle Palaeolithic the northern and southern edges of the Basin were occupied on a regular basis (Di Modica 2011; Pirson \& Di Modica 2011). During the Upper and Final Palaeolithic the northern slope of the Mons Basin was visited by human groups taking advantage of the very valuable local raw materials (Letocart 1970; Miller et al. 2004; Moreau et al. 2013). Eventually, during the Neolithic, flint mines were dug both in the north and the south of the area. The oldest clue of mining, identified in Obourg, could be as old as the 4600-4500 BCE period corresponding to the Middle Neolithic I (Jadin et al. 2008; Collin in press).

Of all the mining sites of the Mons Basin, Spiennes was certainly the most important as shown by the extension of knapping waste on the surface, which is spread on a hundred hectares (Collet et al. 2008). The flint mines of Spiennes were in activity from the Middle Neolithic II (Michelsberg Culture, 4300-3600 BCE) to the Final Neolithic (Deûle-Escaut Group, 2900-2300 BCE). According to the thirty-three radiocarbon dates available today mining activities started around 4350 BCE and ended by 2800 BCE, or even in 2300 BCE (Figure 2 and Table 1). Flint extracted from the mining site during 1,500 years at least was used to produce flaked axeheads (to be polished) but also blades and large flakes. Some of those were used locally but a large number were exported. For instance, in the lithic assemblages of the Middle Neolithic II in Hainaut and Walloon Brabant, the Spiennes flint is one of the main raw materials. In some settlement sites such as in Thieusies (Vermeersch et al. 1990), the usual toolkit is even made mostly of Spiennes flint. In the Nivelles area at a distance of 20 to $40 \mathrm{~km}$ from Spiennes, the relative proportions of the various raw materials originating from the Mons Basin show that Spiennes flint is still the most used (Hubert 1982). In sites further afield it is found in the form of polished axes, blades and large flakes, produced on the mining site. Such specialised Spiennes flint productions were identified up to $160 \mathrm{~km}$ away from the mining site (Bostyn \& Collet 2011). During the Final Neolithic the 
lithic assemblages of several Deûle-Escaut Group settlements in the north of France indicate the persistence of the importation of mining products from Spiennes, mostly axes (Allard et al. 2010). While some progress were lately made distinguishing macroscopically and mesoscopically (at an intermediate scale between macroscopic and microscopic; thanks to the use of a stereomicroscope) Spiennes flint from other flint resources in the Mons Basin and North of France (Allard et al. 2010; Bostyn \& Collet 2011), further studies will be necessary to discriminate for instance Spiennes flint from Rijckholt flint and help to positively establish the distribution network of raw material. Geochemical analyses let also expect new developments in that field (Collin 2016).

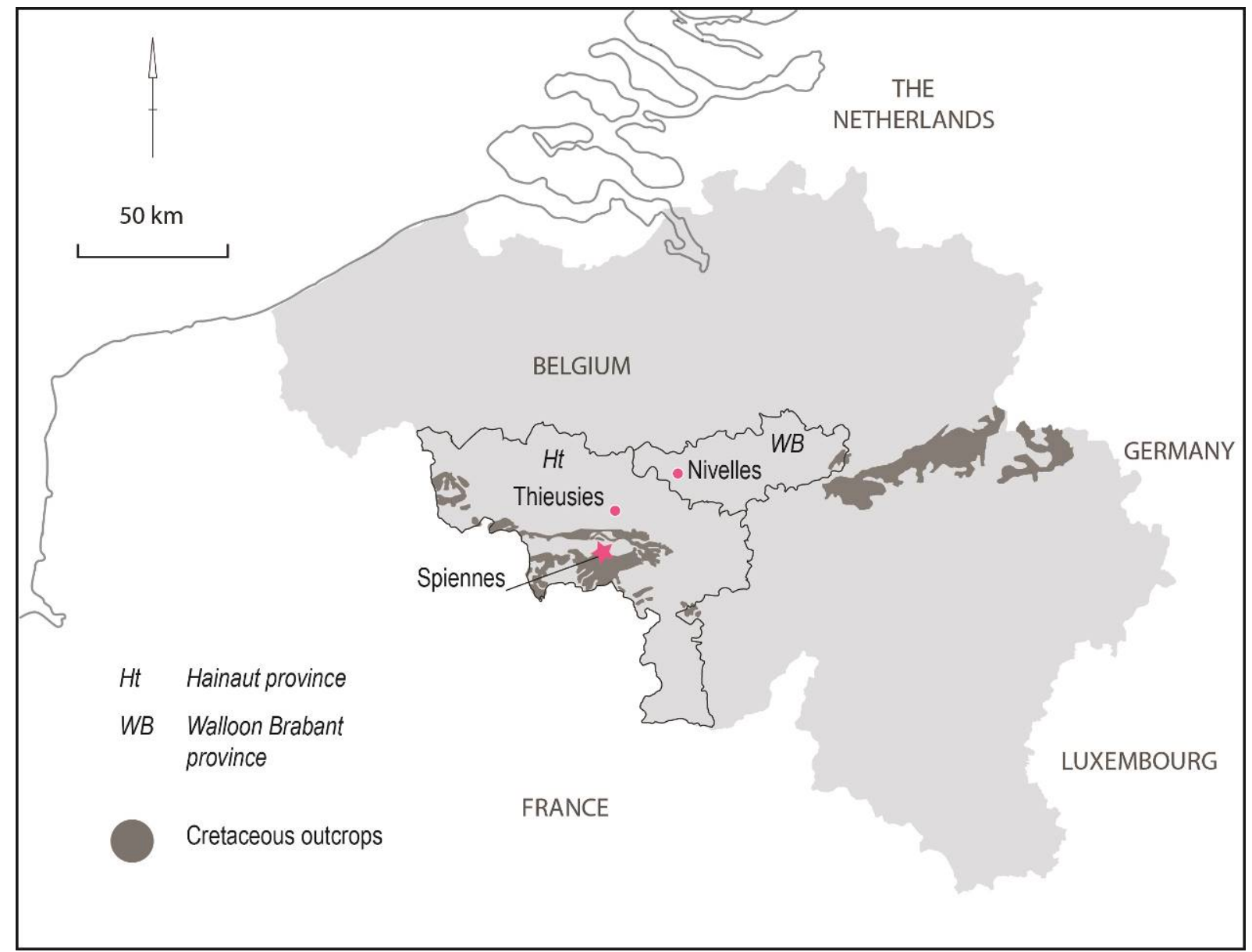

Figure 1. Location of Spiennes (Hainaut Province, Belgium)

\section{Purpose of the paper}

This paper intends to explore the geological, social and technical contexts in which the Neolithic miners of Spiennes worked and which allowed the development of raw material procurement strategies both varied and complex and made possible both the economic importance of the site and its extraordinary duration. In this regard the paper synthesizes the scattered data collected during nearly 150 years but also relies on new results obtained during the latest excavations. For a couple of decades the flint mines of Spiennes have been the object of a sustained attention from the Public Service of Wallonia (SPW) and the Society for Prehistoric Research in Hainaut (SRPH). Of course the site is far from being excavated in its totality and some of the results are still preliminary, however the data collected already allow to outline the main strategies of raw material procurement at Spiennes and to make some comparisons with other European Neolithic mining sites. 
Table 1. Radiocarbon dates and context. Abbreviations: PSP - Petit-Spiennes mining area; CAC - Camp-à-Cayaux mining area; Wampe - Versant de la Wampe mining area;

\begin{tabular}{|c|c|c|c|c|c|c|c|}
\hline & Lab number & Area & Context & BP & Cal $1 \sigma$ & Cal $2 \sigma$ & Matter \\
\hline 1 & Lv-1566 & PSP & exploitation level (406b, shaft 79.3) & $5510 \pm 55$ & $4447-4329$ & $4459-4258$ & elk antler \\
\hline 2 & GrN-4674 & CAC & hearth (J. Verheyleweghen 1953) & $5420 \pm 75$ & $4352-4081$ & 4444-4047 & charcoal \\
\hline 3 & GrA-46577 & CAC & exploitation level (de Loë 1912) & $5200 \pm 45$ & $4042-3968$ & $4229-3848$ & animal bone \\
\hline 4 & OxA-8874 & PSP & shaft filling (406b, shaft 79.1) & $5160 \pm 45$ & 4041-3848 & 4050-3802 & human bone \\
\hline 5 & KN-1016 & CAC & probably head of shaft (J. Stevens, nr 70) & $5140 \pm 40$ & 3987-3816 & 4041-3801 & charcoal \\
\hline 6 & Poz-49942 & enclosure & pit inside the enclosure (SP 79) & $5140 \pm 40$ & 3987-3816 & 4041-3801 & selected charcoal \\
\hline 7 & GrA-46571 & CAC & probably head of shaft (J. Stevens, $\mathrm{nr} 80$ ) & $5130 \pm 45$ & 3981-3811 & $4040-3798$ & human bone \\
\hline 8 & Lv-1598 & PSP & shaft filling (406b, shaft 53.2 ) & $5100 \pm 65$ & 3968-3801 & $4040-3713$ & animal bone \\
\hline 9 & GrA-46567 & PSP & exploitation level (393c, shaft 20) & $5085 \pm 45$ & 3956-3804 & $3973-3780$ & selected charcoal \\
\hline 10 & GrA-46574 & CAC & head of shaft (F. Hubert 1965, nr 3) & $5080 \pm 45$ & 3953-3804 & 3971-3775 & human bone \\
\hline 11 & Oxa-10553 & PSP & shaft 5 (J. Breuer 1930, shaft 5) & $5070 \pm 40$ & 3947-3802 & 3964-3778 & human bone \\
\hline 12 & Poz-49941 & enclosure & upper part of the outer ditch (SP 66) & $5040 \pm 35$ & $3941-3783$ & $3953-3714$ & charcoal \\
\hline 13 & Poz-49939 & enclosure & bottom of the outer ditch (SP 69, Gr 5) & $5025 \pm 35$ & 3938-3766 & 3944-3712 & selected charcoal \\
\hline 14 & GrA-50559 & CAC & probably head of shaft (J. Stevens, $\mathrm{nr} 44$ ) & $5015 \pm 45$ & $3932-3711$ & 3943-3705 & human bone \\
\hline 15 & Poz-49944 & enclosure & bottom of the outer ditch (SP 78, TIV) & $4980 \pm 35$ & 3790-3707 & $3931-3660$ & animal bone \\
\hline 16 & Oxa-3196 & PSP & unknown, railway trench? & $4830 \pm 80$ & $3703-3522$ & $3782-3376$ & human bone \\
\hline 17 & GrA-46576 & CAC & pit? (de Loë 1925) & $4810 \pm 45$ & 3649-3528 & 3696-3384 & human bone \\
\hline 18 & Poz-49940 & enclosure & middle part of the inner ditch (SP 67) & $4805 \pm 35$ & $3642-3533$ & $3654-3521$ & selected charcoal \\
\hline 19 & GrA-46569 & CAC & probably head of shaft (J. Stevens, nr 31) & $4695 \pm 45$ & $3621-3376$ & $3632-3368$ & human bone \\
\hline 20 & GrA-46570 & CAC & probably head of shaft (J. Stevens, nr 60) & $4645 \pm 45$ & $3510-3364$ & $3627-3348$ & human bone \\
\hline 21 & GrA-35961 & Wampe & head of shaft (F. Hubert 1975) & $4625 \pm 35$ & 3498-3361 & $3518-3348$ & red deer antler \\
\hline 22 & GrA-35963 & Wampe & head of shaft (F. Hubert 1975) & $4615 \pm 35$ & 3497-3355 & $3517-3141$ & red deer antler \\
\hline 23 & Beta-194770 & PSP & exploitation level (393c, shaft 11) & $4580 \pm 40$ & $3494-3129$ & $3500-3104$ & red deer antler \\
\hline 24 & Beta-194771 & PSP & exploitation level (393c, shaft 11) & $4550 \pm 40$ & $3366-3118$ & $3486-3100$ & red deer antler \\
\hline 25 & Poz-49943 & enclosure & inner ditch (SP 69, Gr 7) & $4535 \pm 35$ & 3359-3117 & 3364-3102 & animal bone \\
\hline 26 & GrA-46555 & PSP & shaft filling (393c, shaft 11) & $4525 \pm 40$ & $3353-3114$ & 3364-3097 & human bone \\
\hline 27 & GrA-35954 & PSP & head of shaft (393c, shaft 28) & $4505 \pm 35$ & 3338-3106 & 3353-3095 & red deer antler \\
\hline 28 & Beta-110 683 & PSP & shaft filling (393c, shaft 11) & $4500 \pm 50$ & 3338-3103 & $3362-3027$ & human bone \\
\hline
\end{tabular}




\begin{tabular}{lllccccc}
\hline & Lab number & Area & Context & BP & Cal 1 $\boldsymbol{C}$ & Cal 2 $\sigma$ & Matter \\
\hline 29 & Lv-1599 & PSP & shaft filling (406b, shaft 80.4) & $4490 \pm 100$ & $3351-3030$ & $3498-2909$ & red deer antler \\
30 & Oxa-10555 & CAC & head of shaft ( J. Verheyleweghen 1953) & $4480 \pm 40$ & $3332-3096$ & $3349-3026$ & human bone \\
31 & GrA-35959 & CAC & head of shaft (51c, shaft 13) & $4415 \pm 35$ & $3096-2933$ & $3323-2917$ & red deer antler \\
32 & GrA-36129 & PSP & head of shaft (393c, shaft 6) & $4390 \pm 40$ & $3084-2924$ & $3310-2904$ & red deer antler \\
33 & GrA-35958 & CAC & head of shaft (33h, shaft 11) & $4350 \pm 35$ & $3011-2911$ & $3086-2896$ & red deer antler \\
34 & GrA-35960 & CAC & head of shaft (33h, shaft 21) & $4315 \pm 35$ & $3009-2890$ & $3020-2886$ & red deer antler \\
35 & BM-289 & unknown & workshop? (A. Toilliez 1855) & $4230 \pm 130$ & $3010-2588$ & $3327-2474$ & red deer antler \\
36 & GrA-35955 & PSP & shaft filling (393c, shaft 20) & $4200 \pm 35$ & $2887-2704$ & $2897-2671$ & red deer antler \\
37 & GrA-46575 & CAC & head of shaft (de Loë 1925, A3) & $4200 \pm 45$ & $2887-2704$ & $2897-2671$ & human bone \\
38 & GrA-50560 & CAC & pit (J. Stevens 1911, Spiennes D) & $4075 \pm 40$ & $2834-2498$ & $2858-2487$ & human bone \\
39 & GrA-50561 & CAC & pit (J. Stevens 1911, Spiennes E) & $3775 \pm 40$ & $2279-2138$ & $2334-2039$ & human bone \\
\hline
\end{tabular}




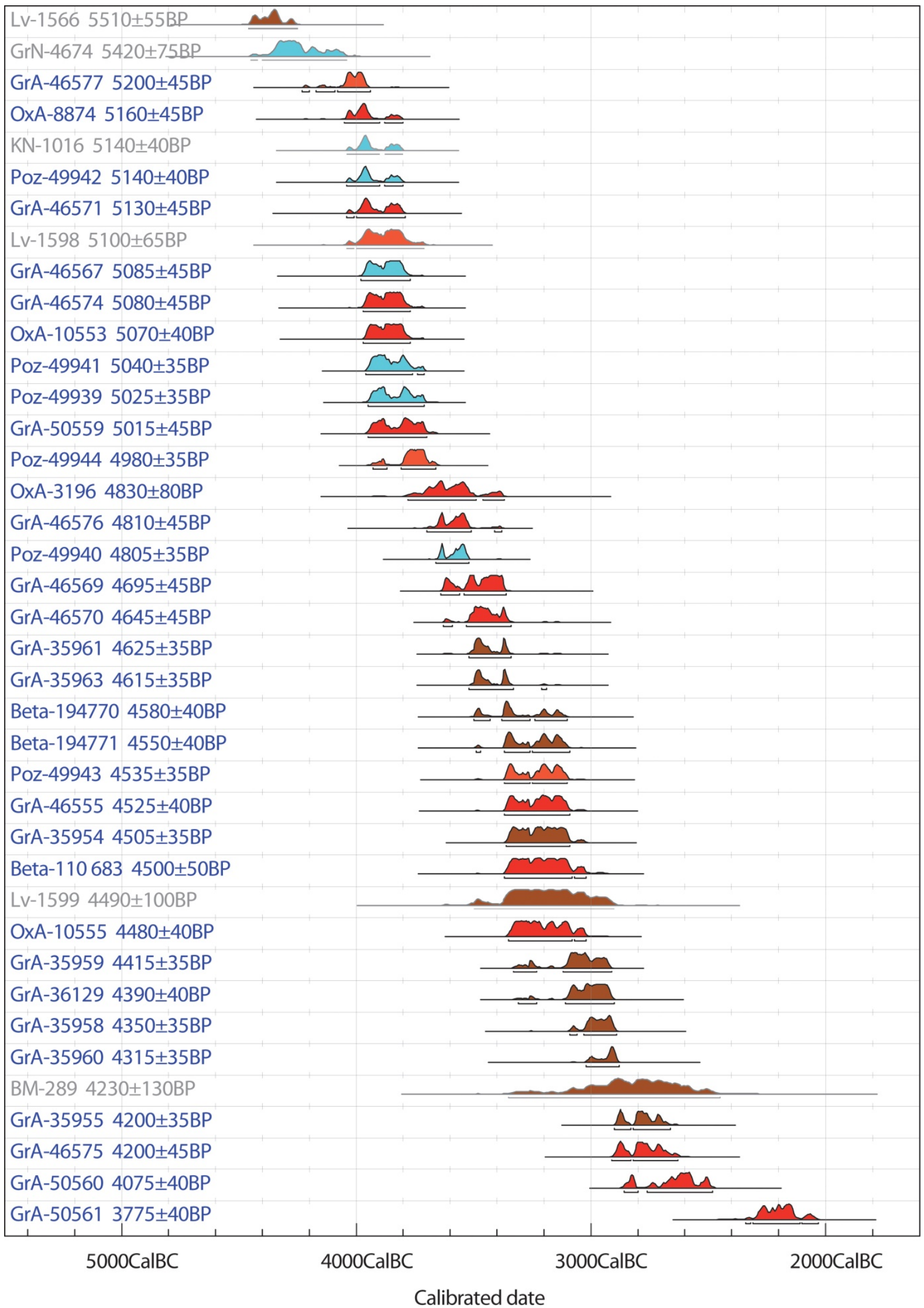

Figure 2. Radiocarbon dates of the Neolithic Flint Mines of Spiennes. Dates obtained on deer antler (brown), wood charcoal (blue), bone (orange), human bone (red); light grey outline for conventional radiocarbon dates, dark blue outline for AMS dates. Graphics by I. Jadin, Royal Belgian Institute of Natural Sciences. (IntCal 13 atmospheric curve (Reimer et al. 2013); OxCal v3.10 Bronk Ramsey (2005); cub r:5 sd:123 prob usp [chron].) 


\section{Geological context}

The site of Spiennes offers both extremely rich flint resources and a specific geographical configuration that certainly made the discovery of the deposit easy in the Neolithic (Figure 3). The southern edge of the Mons Basin presents a cuesta landscape oriented east-to-west with an abrupt slope to the south and a gentle slope to the north. The cuesta is cut through by several rivers, tributaries and sub-tributaries of the Haine River. In the area of Spiennes the Trouille River carved a steep valley that splits the cuesta in two: east the plateau of Camp-à-Cayaux and west the plateau of Petit-Spiennes. The steep slopes of the Trouille River valley exposed a $20 \mathrm{~m}$ thick layer of chalk bedrock of the Spiennes Formation that is visible right under the topsoil. There, the flint seams are regularly spaced 1 metre apart, sometimes $50 \mathrm{~cm}$. The Neolithic flint mines were clustered on the slopes and the plateaus directly overlooking the valley, which shows its likely role in the discovery of the site by Neolithic communities. Further west, the Wampe River also cuts through the cuesta and reveals an important sequence of Spiennes Chalk. Neolithic mining was identified on the slopes overlooking the right bank of the river (Hubert 1976a). Here also the exposure of the flint seams could have facilitated the discovery of the deposit. To this day, however, no mining features are known on the left bank of the river, facing the 'Versant de la Wampe' mining zone. All three mining zones - Camp-à-Cayaux, Petit-Spiennes and Versant de la Wampe - are considered as a single site, Spiennes (Figure 4).

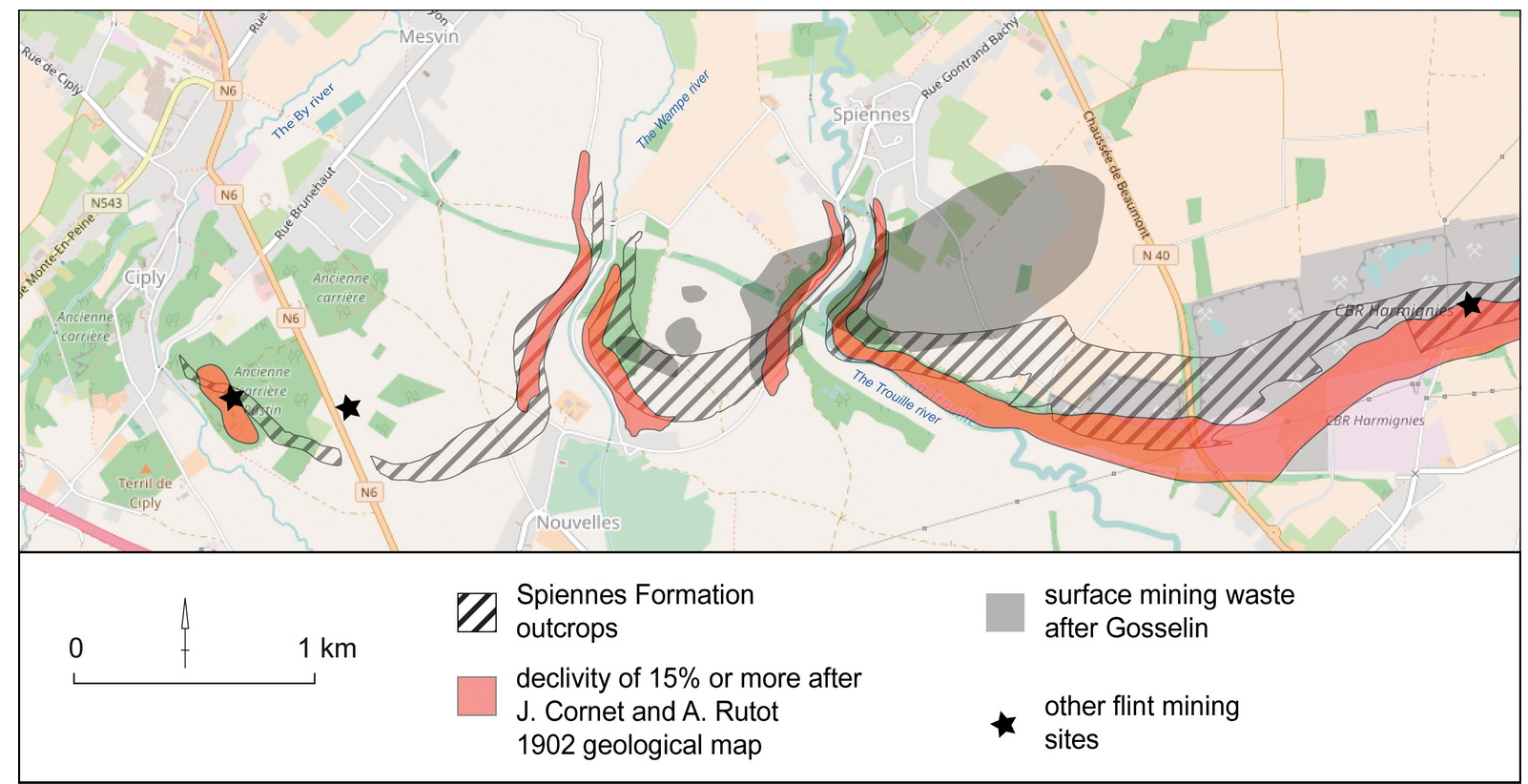

Figure 3. The Neolithic flint mines of Spiennes on the southern edge of the Mons basin. Graphics by $\mathrm{M}$. Woodbury, SPW. Map: OpenStreetMap contributors.

On the banks of the rivers Trouille and Wampe as on the southern edge of the cuesta, the chalk bedrock outcrops at the surface; on the plateaus it is covered by a several-metre-thick loess mantle. Between the loess mantle and the chalk bedrock lies a layer of glauconiferous tertiary sands and, at places, gravels belonging to a system of staged alluvial terraces (Briart et al. 1868; Haesaerts 1984). In Petit-Spiennes, in the westernmost part of the mining site, the Tertiary and Quaternary cover on top of the chalk bedrock reaches a thickness of 6 to 10 metre (Briart et al. 1868). Our own excavations undertaken in Petit-Spiennes in 1997, 300 metres to the north of the railway trench (Figure $4 \mathrm{nr} 2$ ), also showed that the top of the chalk bedrock was reached 6 m below surface (Collet \& Van Neer 2002). 


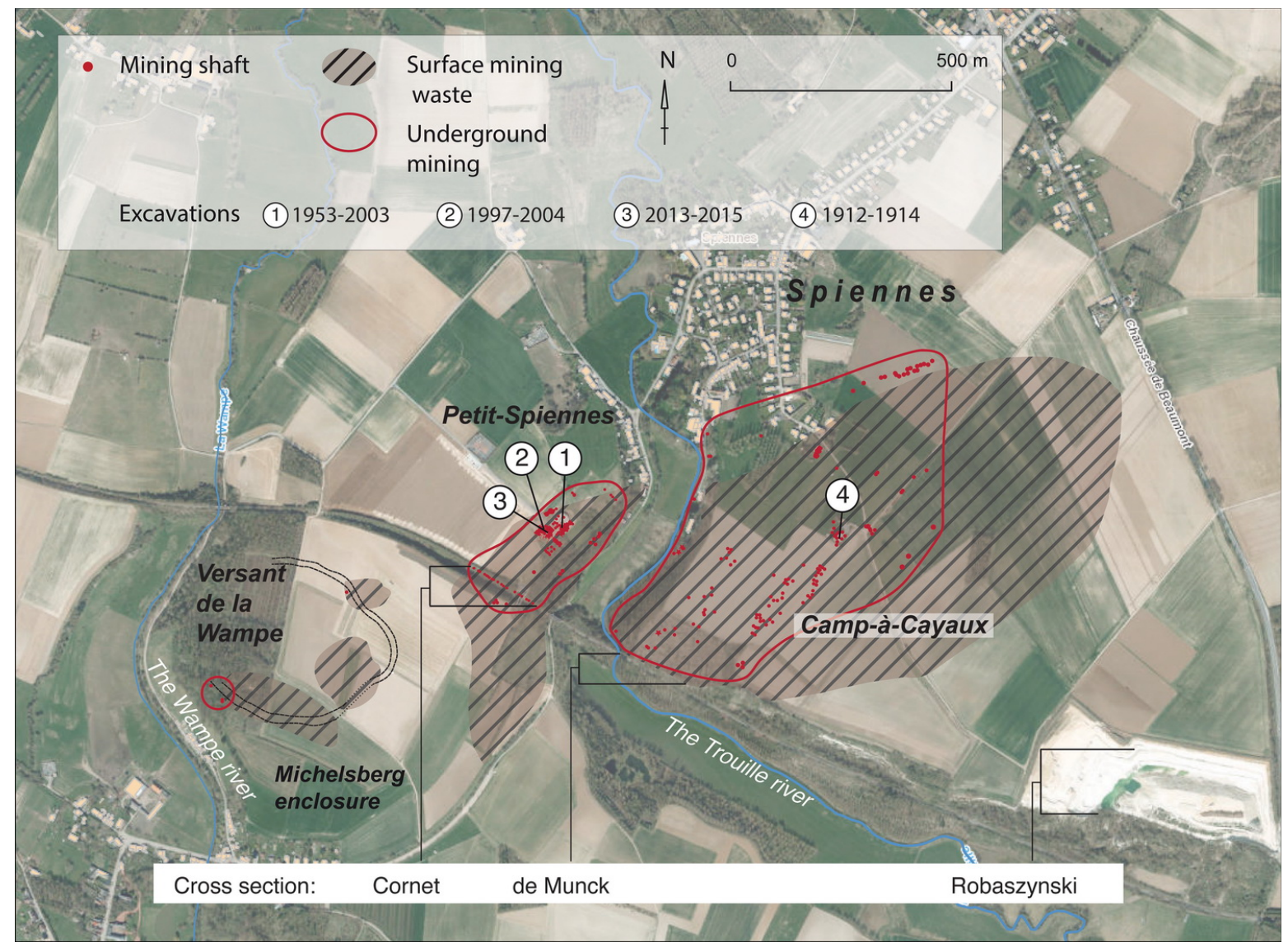

Figure 4. The Neolithic flint mines, surface extent of the mining waste and localisation of the known mining zones. (Surface extent after Gosselin (1990); background picture: SPW). Graphics by M. Woodbury, SPW.

Three geological cross sections allow evaluating the quality and the accessibility of the flint seams on the site of Spiennes. The oldest is the 'Cornet cross section' that was drawn in 1867 during the trenching of the railway that ran across the Petit-Spiennes plateau. It illustrates the Tertiary and Quaternary cover in detail but the flint seams are schematic (Figures 4 and 5). The second cross section was recorded along the railway embankment in Camp-à-Cayaux (Figures 4 and 6). The Quaternary cover is lacking because the cross section is located on the edge of the plateau, but it offers a unique view of the underground of Campà-Cayaux in the area of the mining site, in particular its flint content. The third cross section was drawn in the Omya Quarry, outside of the mining site at the edge of the Camp-à-Cayaux plateau (Figures 4 and 7). It is very interesting as it illustrates dramatically the richness in flint of the Spiennes Formation compared to the underlying formations of Nouvelles and Obourg as well as the faults in the southwestern edge of the cuesta and the dipping flint seams that can be seen.

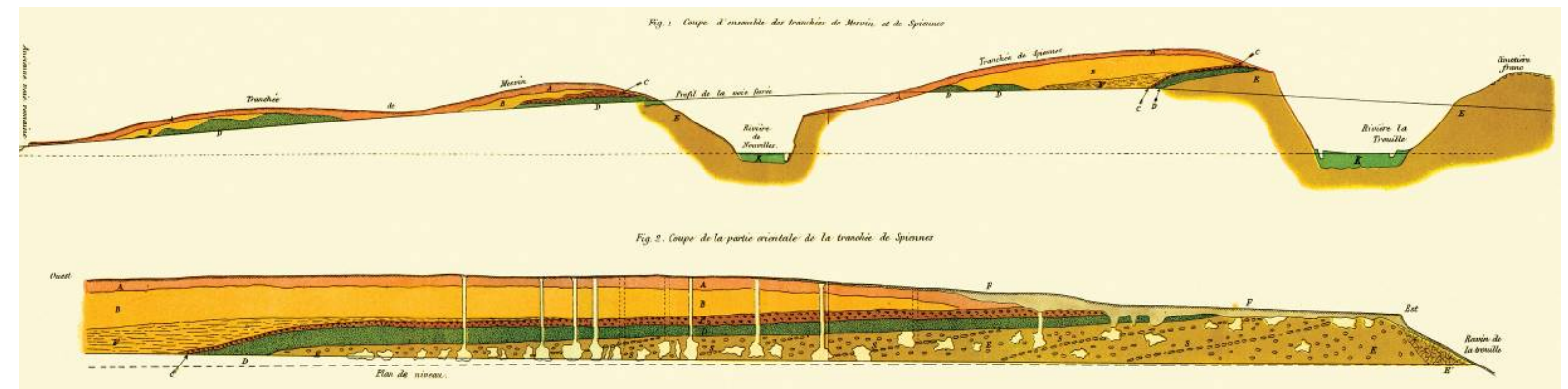

Figure 5. Petit-Spiennes. 'Cornet' cross section drawn during the trenching of the railway in 1867 (Briart et al. 1868). 


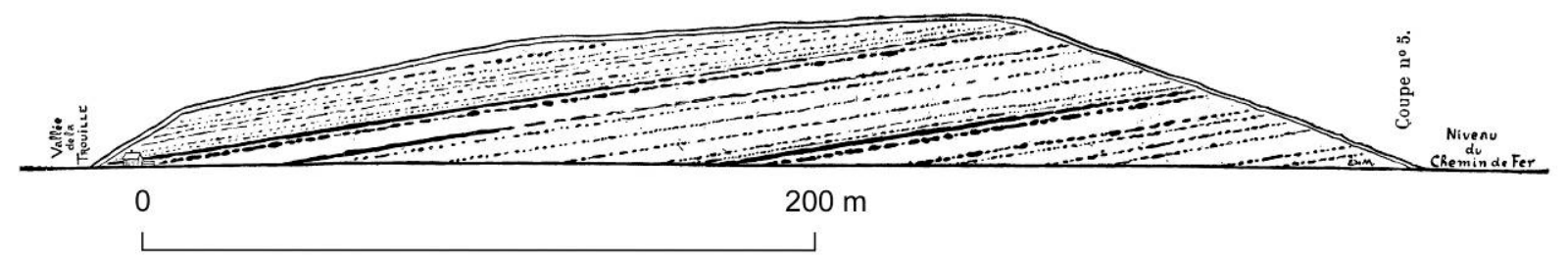

Figure 6. Spiennes. Cross section drawn along the railway embankment showing the high number of flint seams in Camp-à-Cayaux (de Loë \& de Munck 1891).

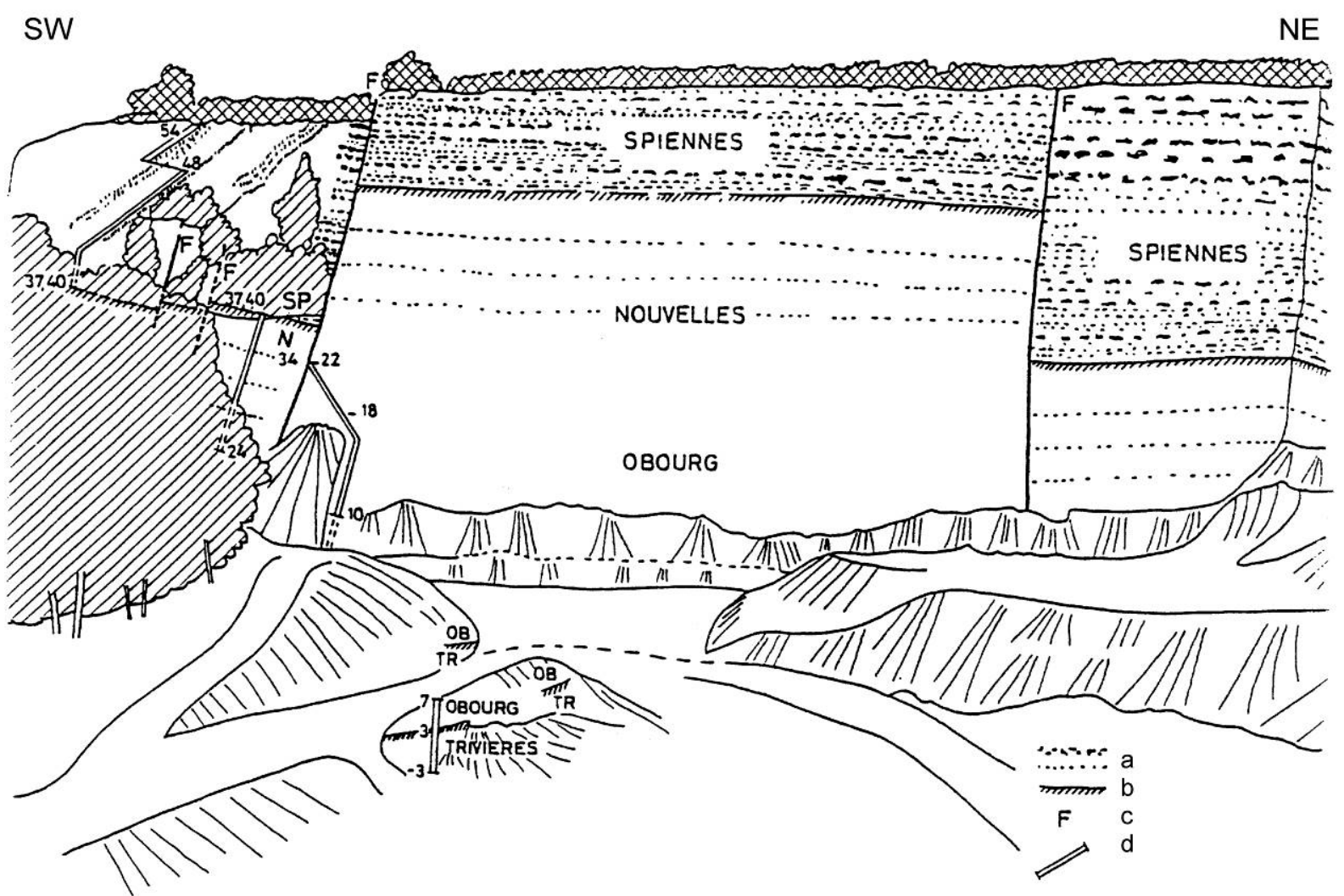

Figure 7. Spiennes. Cross section drawn in the Omya Quarry, at the edge of the Camp-à-Cayaux plateau (Robaszynski \& Christensen 1989).

The flint extracted by the Neolithic miners comes from the Spiennes Chalk Formation which belongs to the Late Cretaceous period (Late Late Campanian). Outcrops of that formation are found in the Mons Basin from Hautrage in the west to Havré in the east. To the south large outcrops appear from the village of Ciply in the west to Villers-Saint-Ghislain in the east. The Spiennes Formation is rich in large flint nodules of 10 to $60 \mathrm{~cm}$ thick, either black or black to grey-brown. On the edges of the Basin, the Spiennes Formation is about $20 \mathrm{~m}$ thick while it is up to $50 \mathrm{~m}$ in its centre (Robaszynski et al. 2001). The specificity of the Spiennes Formation lies in the large number of flint seams it contains and their regular arrangement. In the cross section recorded along the railway in Camp-à-Cayaux, de Loë and de Munck (1891) counted up to 23 flint seams, sloping to the north-west with a 5 to $8 \%$ dip. These seams have diverse characteristics. According to our own observations they generally consist in beds of flat or round nodules with convoluted extremities ranging in size from 5-10 to $60 \mathrm{~cm}$ (Figure 8). The Camp-à-Cayaux cross section shows, along with the nodular flint seams, the presence at various depths of tabular flint seams formed of very large slabs that can reach 1 to $3 \mathrm{~m}$ long and $30 \mathrm{~cm}$ thick and differ from the nodular seams by their great morphological regularity. Two twin seams are visible in the field (Figure 9). Similar seams were exploited at $16 \mathrm{~m}$ deep by Neolithic miners in the middle of the Camp-à-Cayaux mining 
zone (Figure $4 \mathrm{nr} 4$ and Figure 10). In Petit-Spiennes several nodular flint seams are also visible in the railway trench. Isolated flint nodules between these well-formed seams were recorded by A. Briart and F.-L. Cornet (Figure 5).

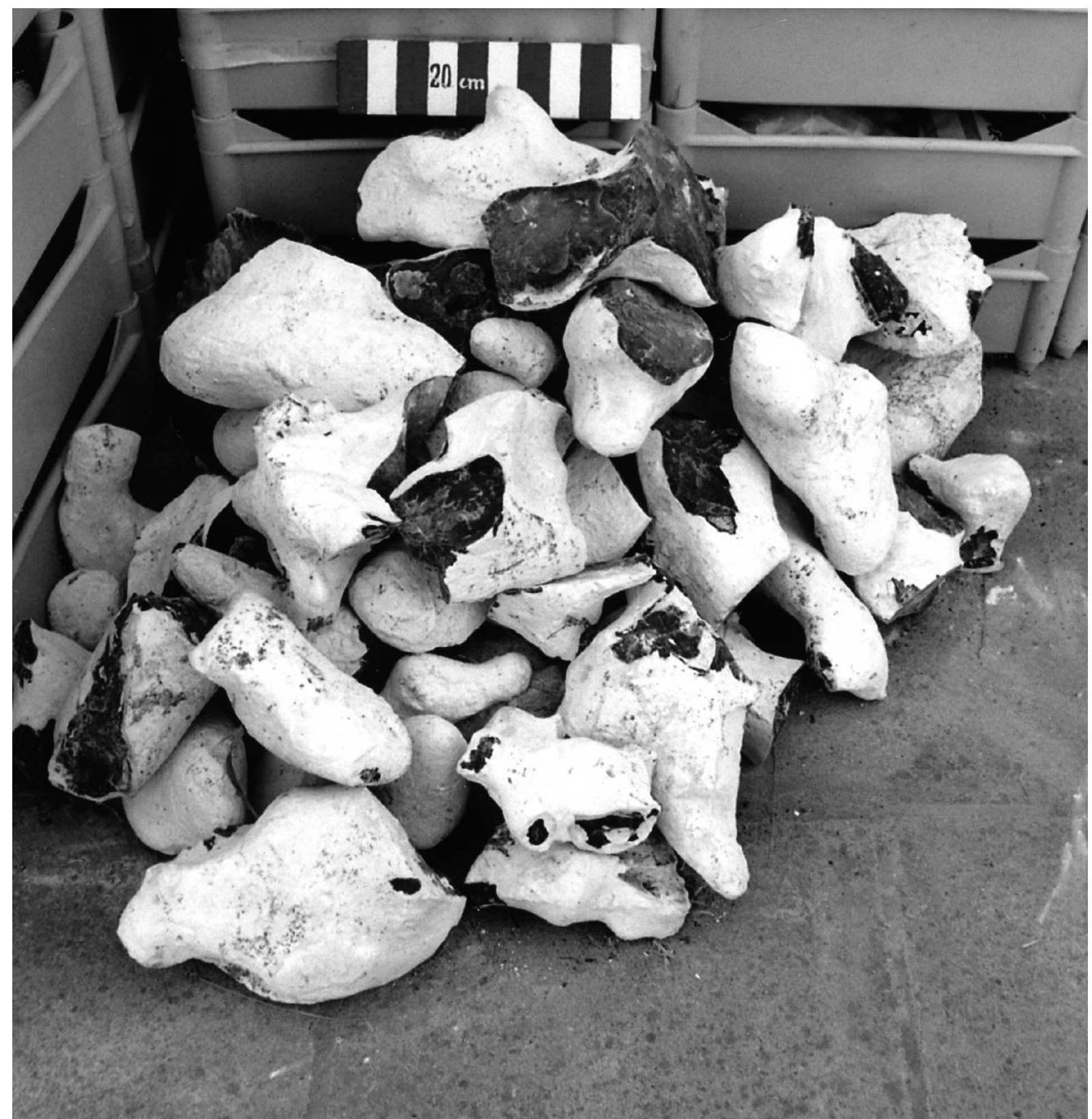

Figure 8. Spiennes. Examples of rejected nodular flint in the ST20 shaft of Petit-Spiennes, 1999-2004 excavations. Photo by J. Lech.

\section{Social context}

By the second half of the 5th millenium BCE, many flint mines dedicated to the mass production of polished axeheads appear in North-West Europe, Spiennes among them, at a time when those tools become common in settlement sites (Giligny et al. 2012). The populations who exploited the mines in Spiennes belong to the farming communities who settled the Mons Basin at the end of the 5th millennium BCE. In the Michelsberg enclosure of Thieusies, Spiennes flint material is both numerous and of quality (Vermeersch et al. 1990). The assemblage yields typical mining products such as large fragments of carefully polished axeheads and long and robust blades, which point to a direct or privileged relation with the 
mining site of Spiennes. At the very end of the 5th or at the beginning of the 4th millennium BCE by the time of the Michelsberg culture (Table $1 \mathrm{nr} 6,12,13$ and 15), an enclosure was built right on the Petit-Spiennes plateau, some $400 \mathrm{~m}$ as the crow flies from the excavated features of the Petit-Spiennes mining zone. This commanding position allowed for a panoramic view of many kilometres around the settlement.

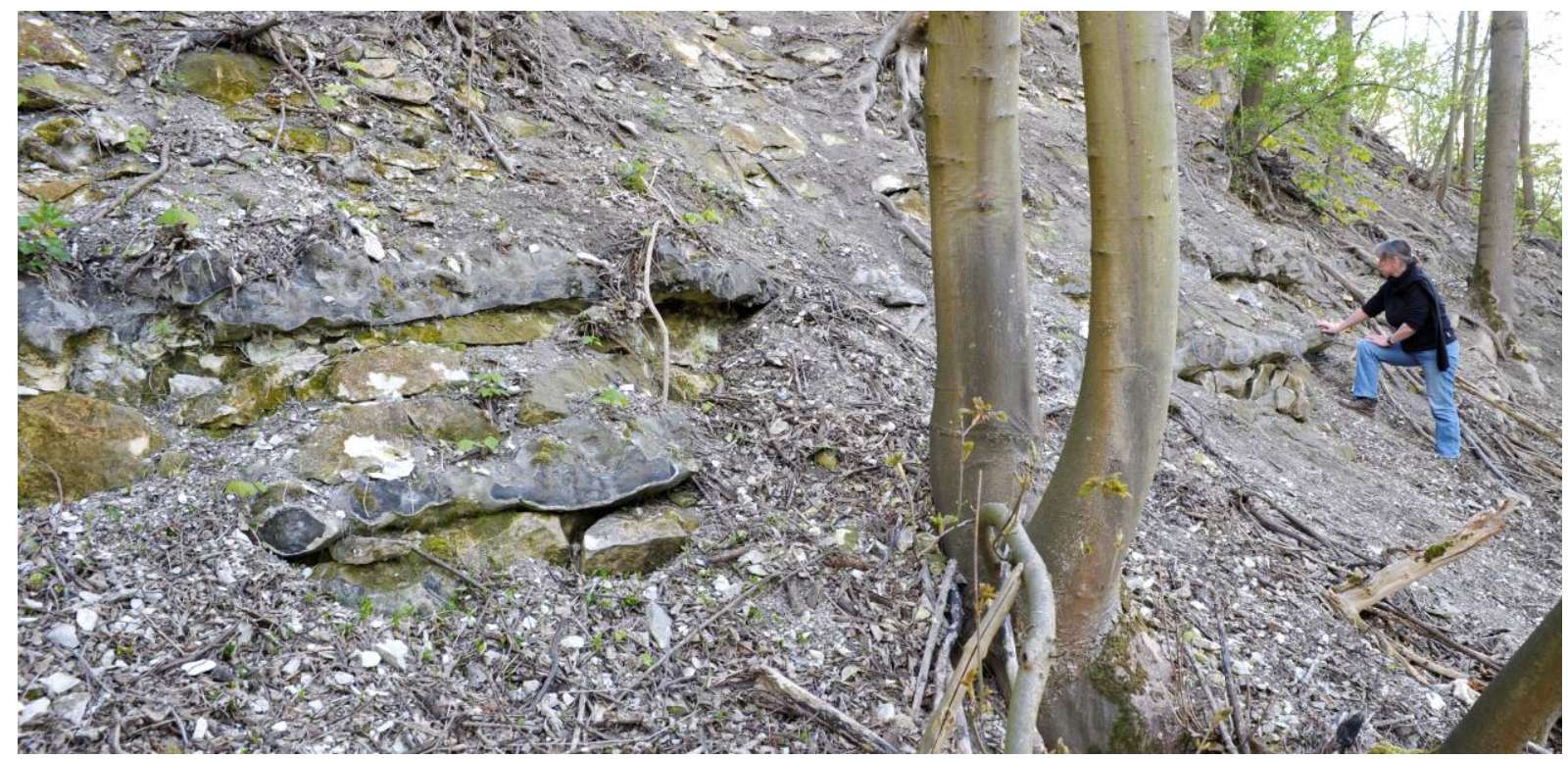

Figure 9. Spiennes. Twin tabular flint seams in the railway embankment in Camp-à-Cayaux. Photo by M. Woodbury, SPW.

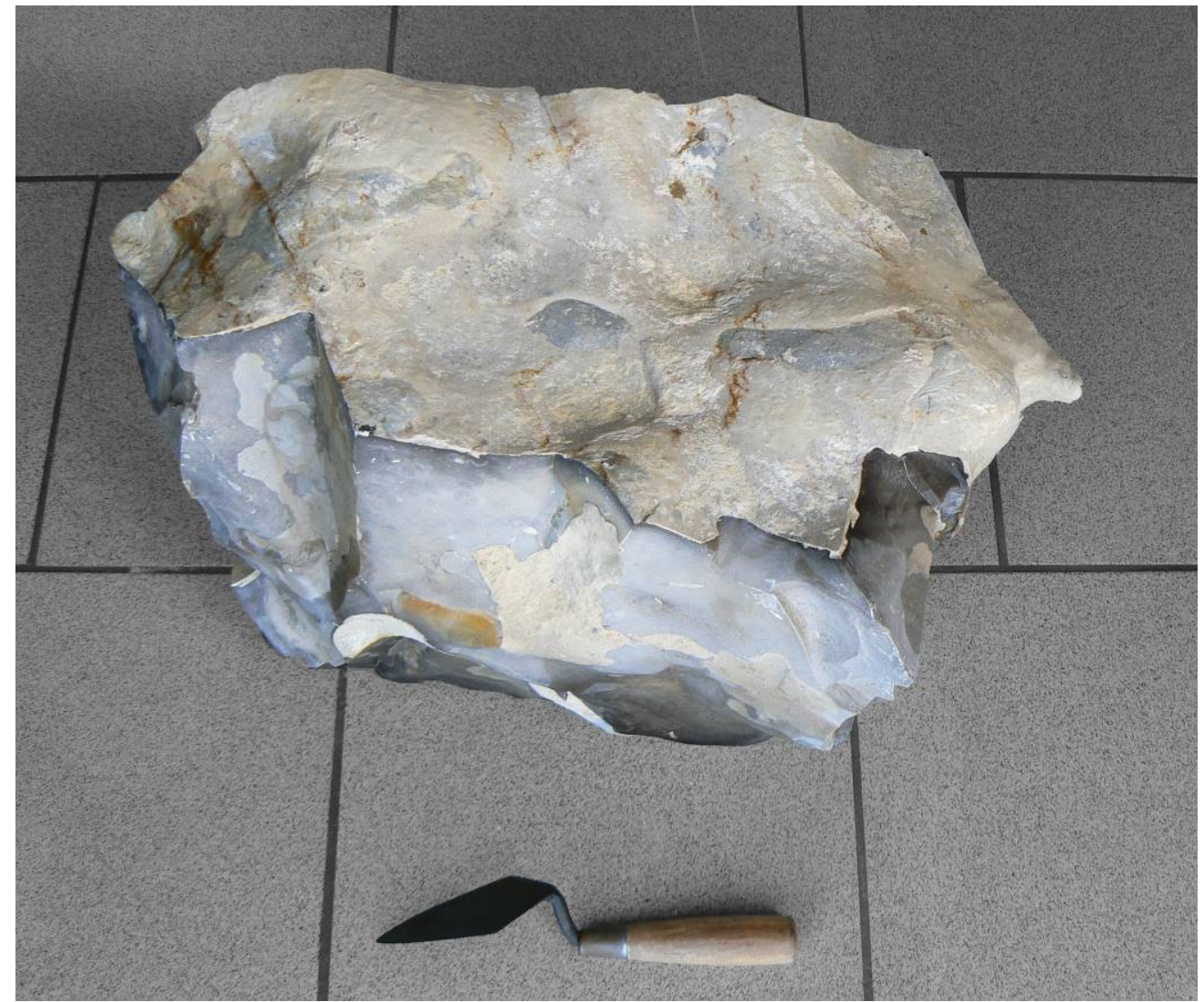

Figure 10. Spiennes. Fragment of a slab abandoned in the 16m deep shafts excavated between 1912 and 1914 . Photo by M. Woodbury, SPW. 
Excavations between 1966 and 1979 by François Hubert have revealed a wide enclosure made up of two concentric ditches surrounding an area of 14ha. These large flat-bottomed ditches from 2.5 to $8 \mathrm{~m}$ wide and from 1.3 to $2.45 \mathrm{~m}$ deep must have laid adjacent to banks built from the material extracted from the ditches. They ended on the west where the slope was quite steep (Collet et al. 2011).

The settlement must have continued for some centuries but indications are still too sparse to confirm it (Table $1 \mathrm{nr} 18$ and 25). The waste material collected in the ditches testify of a domestic occupation, probably all year long: Michelsberg potsherds, flint tools such as scrapers, retouched blades, borers and burins, grinding stones and polissoirs fragments, faunal remains (Hubert 1971). Palynological data indicate the presence of cultivated fields and cattle grazing areas in the immediate vicinity of the enclosure (Heim 1971). Evidence of animal husbandry is not restricted to the village. While mining shafts were in the process of being filled up in Petit-Spiennes, cattle grazed close by as is shown by the faunal remains discovered in the backfills. They comprise, among other, remains of very young animals and even foetuses (Collet \& Van Neer 2002; Goffette et al. 2014). Breeding activities thus took place more or less simultaneously with mining activities. For a long time domestic remains have been discovered in various places on the mining site, including Camp-à-Cayaux (Clason 1981; Collet 2000), which somewhat singles out the site of Spiennes compared to most European mining sites, which are located away from the living settlements (Collet 2000). Traces of very close village life do not disappear at the end of the Michelsberg period as the recent Neolithic shafts also yield similar evidence (Collet \& Van Neer 2002).

\section{Mining techniques}

Various mining techniques were implemented in the flint mines of Spiennes. Open air quarries and short galleries dug directly in the slope were found in the Camp-à-Cayaux bank of the Trouille River (Figure 11). The presence of chalk debris and knapping waste as well as the discovery of a deer antler tool on the opposite bank suggest that similar mining features once existed on the Petit-Spiennes slope (Collet \& Woodbury 2010). On the edges of the plateau, simple open cast extraction features in pits or shafts with lateral niches are known (Figures 5 and 12). In those, as in the open air quarries on the side of the valley, the miners exploited the first seams they reached.

Next to those simple extraction structures, underground mines were spotted on a surface covering an area of 40 to 50 hectares spread from the edges to the heart of the plateaus. This type of operations has been identified in the three mining zones, that is to say Camp-àCayaux, Petit-Spiennes and the Versant de la Wampe (Figure 4).

\subsection{The Petit-Spiennes mines}

On the Petit-Spiennes plateau, mining features explored since 1953 (Figure $4 \mathrm{nr}$ 1) (Gosselin 1986) as those excavated from the end of the 1990s up to this day (Figure $4 \mathrm{nr} 2$ and nr 3) (Collet \& Van Neer 2002; Collet \& Woodbury 2006; Lavachery et al. 2015) reach a depth of 8 to $10 \mathrm{~m}$. However, as seen in the railway cross section, some shafts as deep as $13 \mathrm{~m}$ could have been dug for flint extraction in the western area of the mining zone. The raw material extracted from those shafts appears under the shape of irregular nodules with convoluted extremities, sometimes quite large, arranged in seams (Figure 13). Their size varies from 5 to $60 \mathrm{~cm}$ long. The irregular shape of the blocks, together with the substantial number of small size nodules (Figure 8), resulted in the rejection of a large quantity of raw material because it was deemed inadequate to the production of axeheads. 


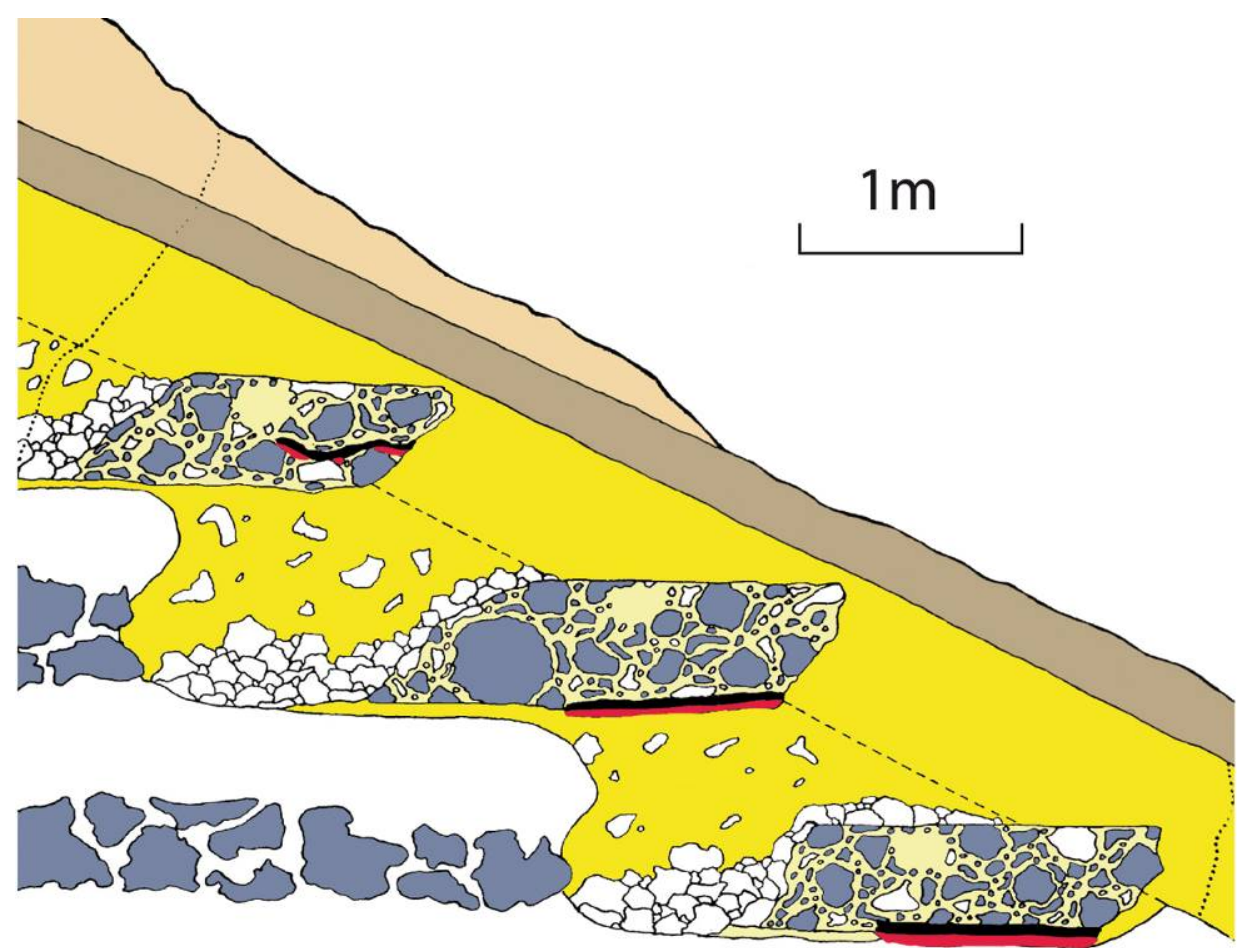

VERHEYLEWEGHEN-JEAN.

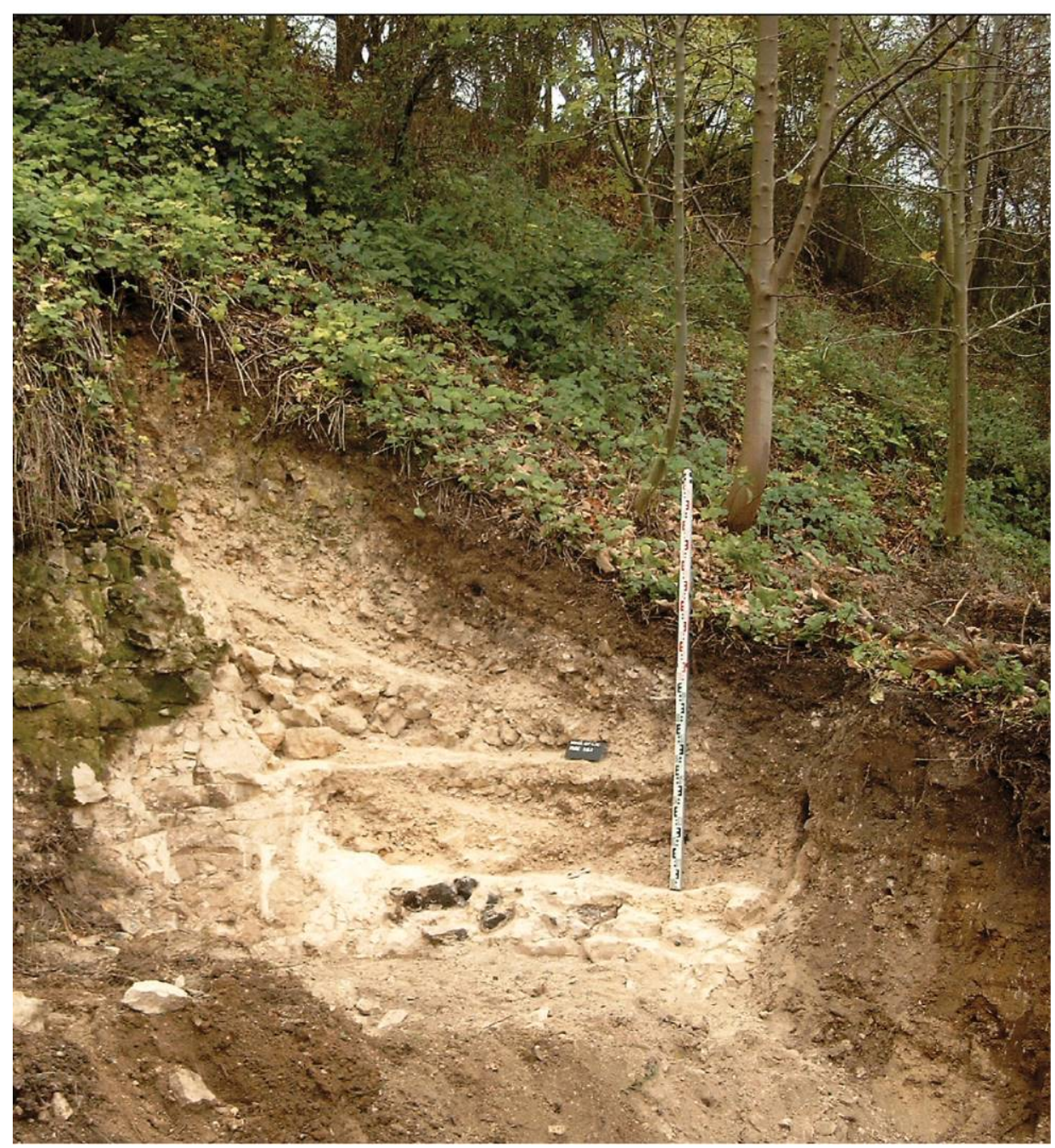

Figure 11. Spiennes. Quarries dug in the bank of the Trouille valley, on the slopes of Camp-à-Cayaux (top: Verheyleweghen 1953 ; bottom: Collet \& Woodbury 2007a). 


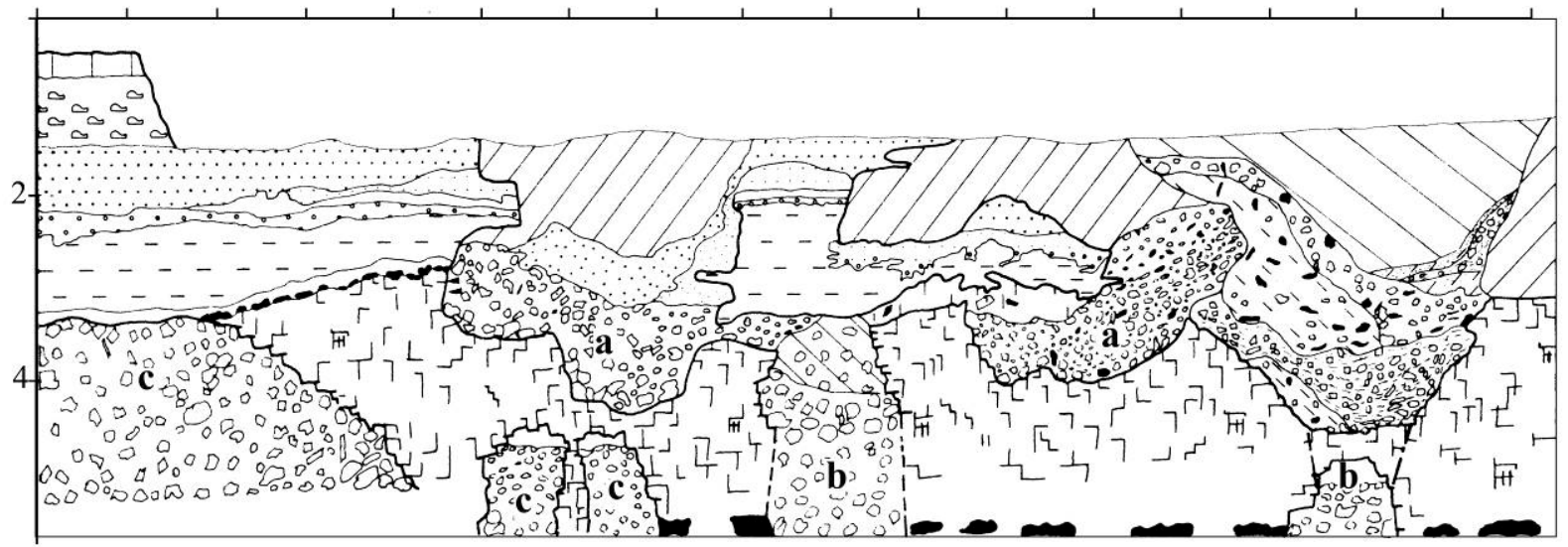

Figure 12. Spiennes. Extraction pits on the edge of the Petit-Spiennes plateau (Hubert 1976b): a. pits; b. shafts; c. galleries. Graphics by A. Hauzeur.

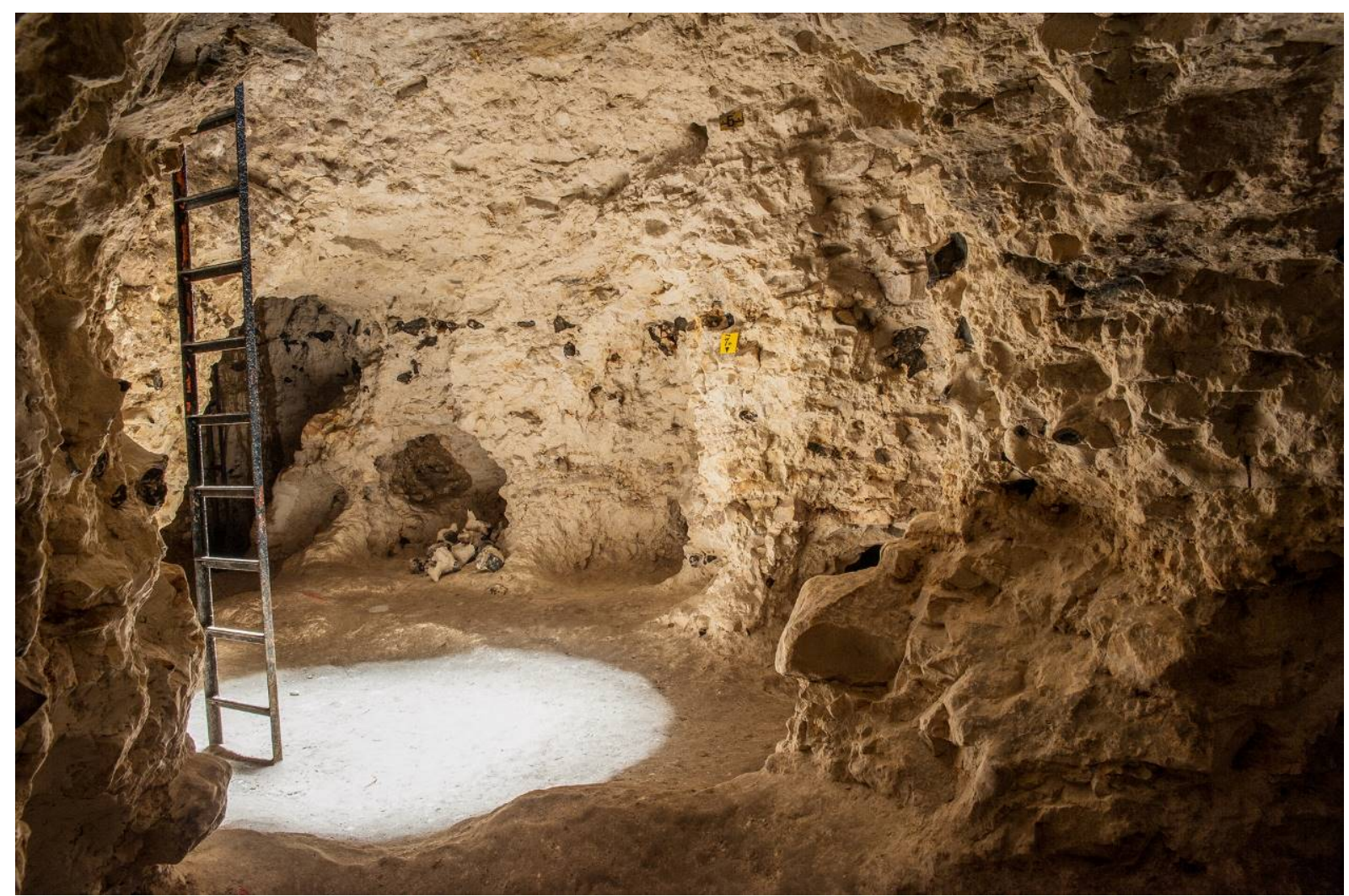

Figure 13. Petit-Spiennes flint mines, excavated by the SRPH from 1953 to 2003. Photo by M. Woodbury, SPW.

In the ST20 shaft of Petit-Spiennes, most of the blocks smaller than $15 \mathrm{~cm}$ were rejected (Figure 14). This drastic raw material selection was made at the time of extraction, in the underground, and the miners abandoned several tons of flint unsuitable for the end products they had in mind. Nodules larger than $15 \mathrm{~cm}$ were tested by striking a few flakes off and were abandoned in turn if considered of poor quality (Figure 15). Only the best blocks were brought to the surface to be knapped on the spot (Collet \& Woodbury 2007b). At this stage of research raw material economy was studied in details only for the ST20 shaft but other structures excavated recently apparently show similar data with an estimated 2 to 4 tons of flint abandoned in each mine. Knowing that on the average the underground surface of each mine is about 20 to $25 \mathrm{~m}^{2}$, the ratio of rejected raw material is far from negligible. This repeating pattern suggests that it was a deliberate strategy. 


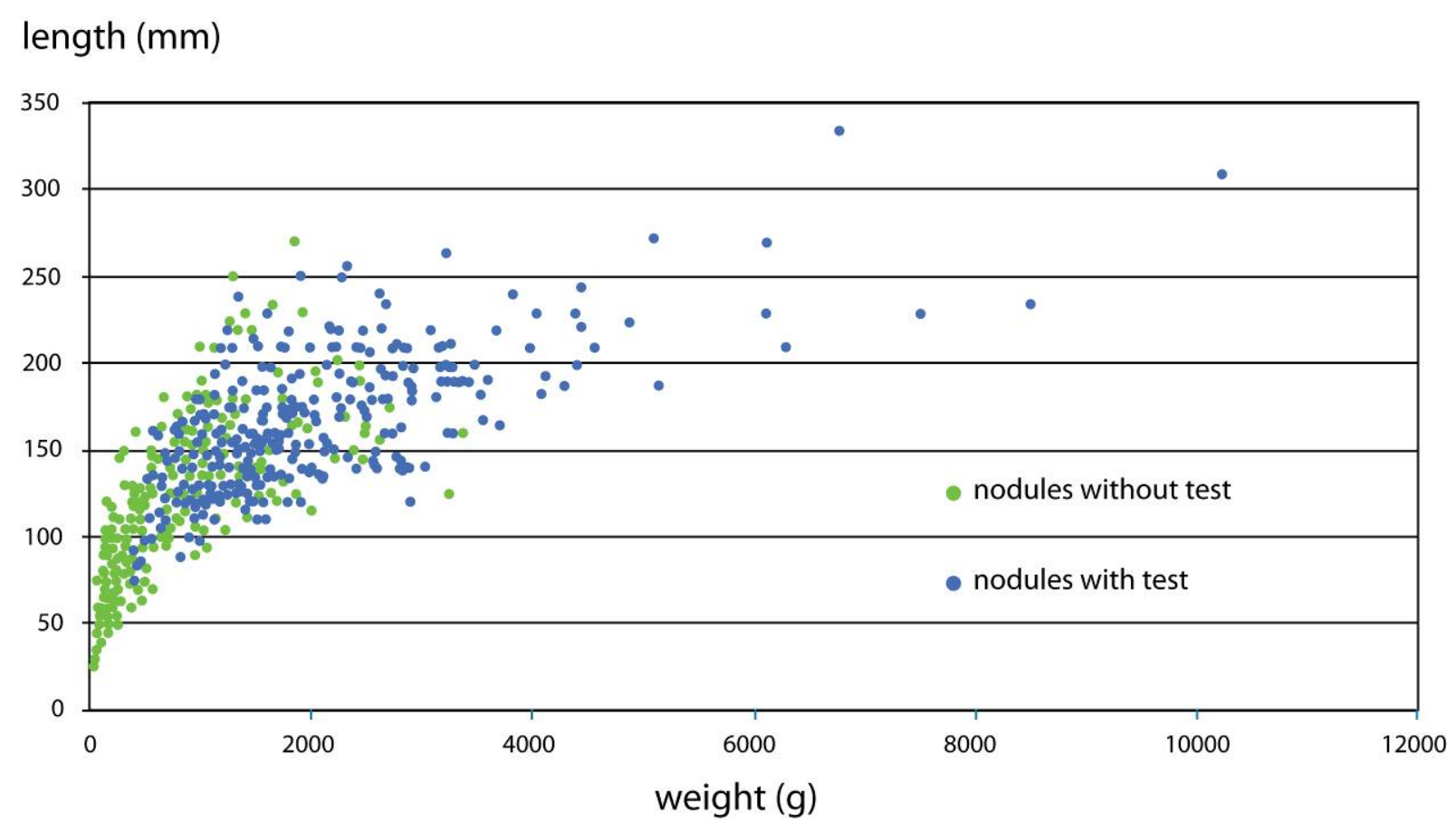

Figure 14. Characteristics of the rejected nodules in ST20 shaft of Petit-Spiennes. Graph M. Woodbury, SPW.

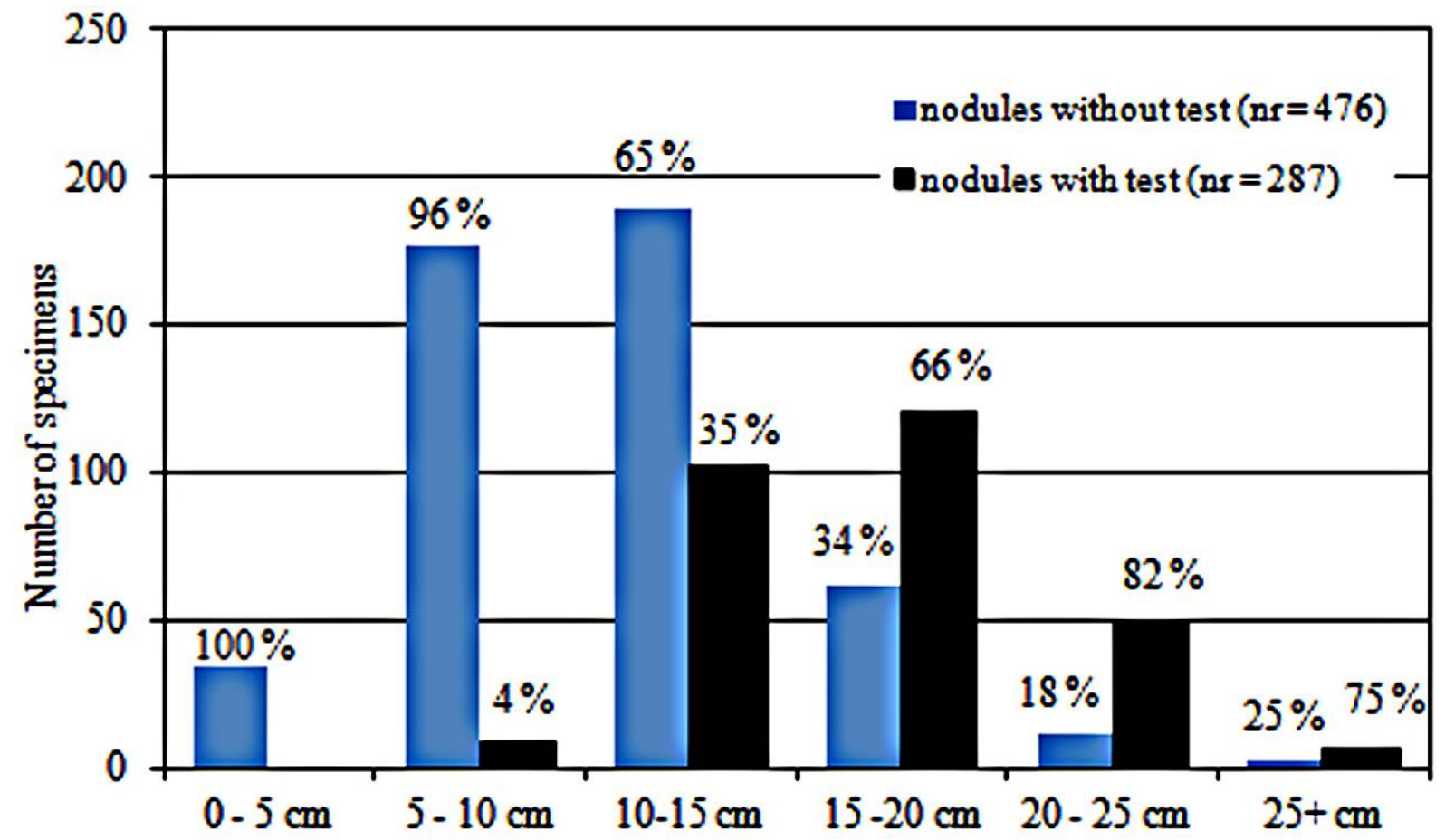

Figure 15. Presence and absence of raw material testing on nodules abandoned in ST20 shaft of Petit-Spiennes. Graph M. Woodbury, SPW.

In the Petit-Spiennes mines only the first flint seams encountered in the digging of the shafts were exploited mostly the second and third seams. In the mines excavated between 1953 and 2003 by the Society for Prehistoric Research in Hainaut the first seam is rather sparse (Figure $4 \mathrm{nr}$ 1). The flint nodules are scattered few and far between. The nodules were extracted on a few square metres only, at the bottom of the access shaft (Figures 16 and 17). 


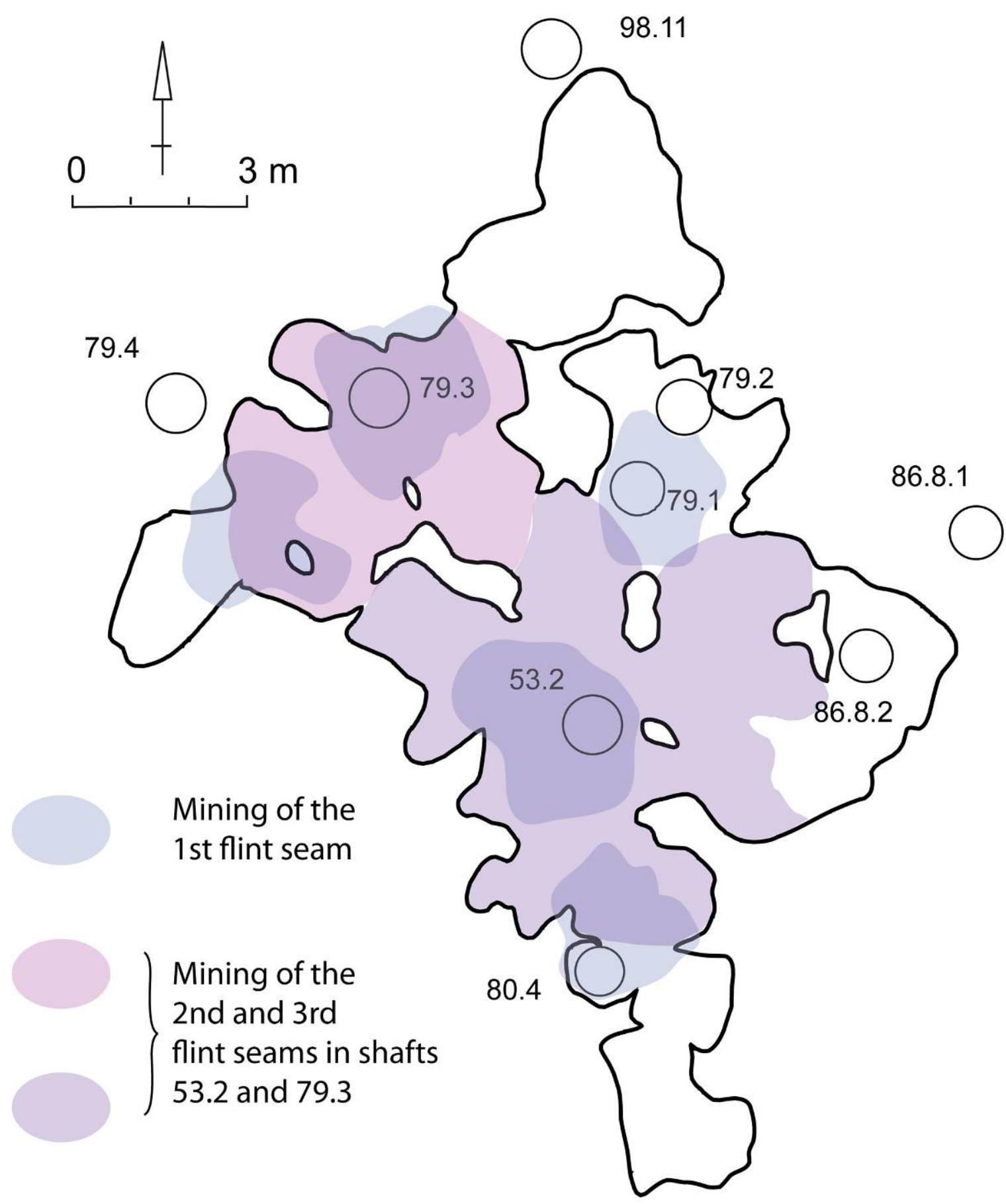

Figure 16. Petit-Spiennes. Underground map of the mines excavated by the SRPH from 1953 to 2003. Graphics by M. Woodbury, SPW after Ladouce (2002) and Gosselin (1986).

Two factors could explain why the miners did not exploit the first seam extensively: its low return and the fact that it is located very close to the top of the chalk bedrock. Indeed the first seam lies $5.8 \mathrm{~m}$ deep, under a mere $1 \mathrm{~m}$ of chalk bedrock. The first archaeologists who studied these mines think that the miners did not extract the first flint seam on a large surface because it would have weakened the roof of the structure (Gosselin 1986). As a matter of fact flint mining focused on the second and third seams, extracted in the same galleries. In the 52.3 shaft, these seams are separated by approximately $1 \mathrm{~m}$ and lie at 7 and $8 \mathrm{~m}$ deep. This explains the height of those galleries, varying between 1 and $2 \mathrm{~m}$, depending on the location. 
Both the spaces at the bottom of the access shaft and in the galleries were found mostly filled up by chalk mining waste. This proves that Neolithic miners abandoned the maximum of the mining waste underground. The stratigraphical study of these archaeological layers in the ST20 and ST6 shafts shows that they were gradually accumulated and trampled at regular intervals. This strongly suggests that the two seams were extracted one after the other, first the bottom one, then the upper one, the miners climbing on the waste dumps. Some of the trampled layers lie very close to the roof of the galleries, showing that very often the miners had to crouch or even crawl to work. The high galleries visible today are the result both of the extraction techniques of the Neolithic miners and of the total excavation by modern archaeologists. Therefore it is most probable that the first seam was extracted after seams 2 and 3 , the miners standing on top of the mining waste resulting from the work in the galleries. This could be what created the bell-shaped space we observe today at the base of the access shafts, sometimes with a horizontal recess at the level of the first seam, resulting from the removal of the flint nodules.

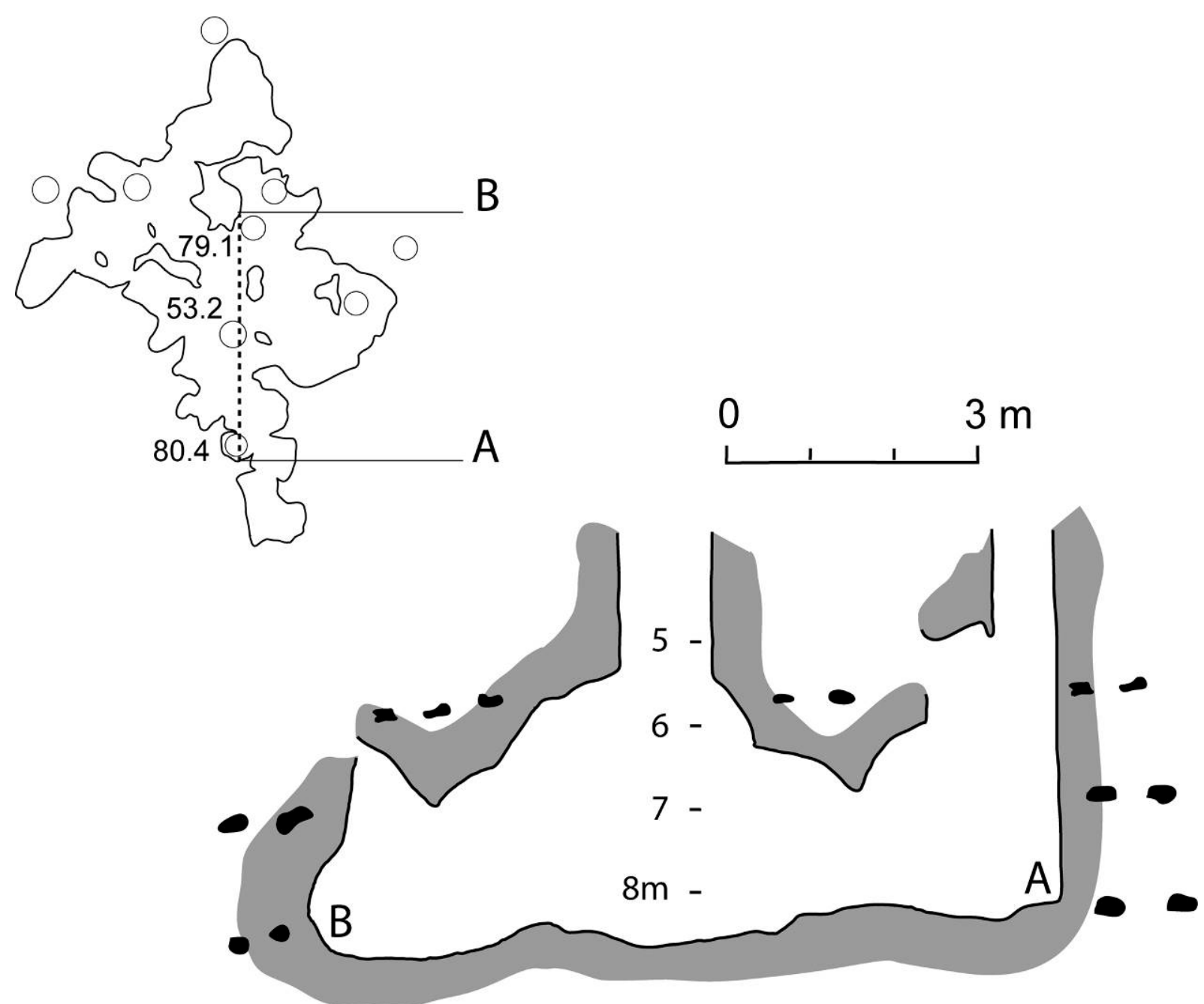

Figure 17. Petit-Spiennes. Cross section of 53.2 shaft in the sector excavated by the SRPH from 1953 to 2003. Graphics by M. Woodbury, SPW after Gosselin (1986).

Several structures showing this mining pattern were dated to the Middle Neolithic (Michelsberg Culture, approximately between 4300 and 3600 BCE). In the area excavated by the SRPH, ST79.3 and ST53.2 shafts were dug according to these extraction techniques and date from 4450 to $4350 \mathrm{cal} \mathrm{BCE}$ and from 3970 to $3800 \mathrm{cal}$ BCE (Table $1 \mathrm{nr} 1$ and $\mathrm{nr}$ 8). 
ST20 shaft, excavated more recently, displays the same pattern and is similarly dated from 3960 to $3800 \mathrm{cal}$ BCE (Table $1 \mathrm{nr}$ 9).

In Petit-Spiennes, however, there are also mines in which only the first seam was extracted. Such is the case of shaft 80.4 in the area explored by the SRPH, where the Neolithic miners dug up to the third seam but, hitting a zone already mined, resorted to working on the first seam before abandoning the mine (Gosselin 1986). In the ST11 feature again it is only the first seam lying between 7.2 and $7.6 \mathrm{~m}$ deep which was extracted (Figure 18). Here the shaft was dug up to $9 \mathrm{~m}$ deep where the miners reached the top of a gallery belonging to an older mine. They did not dig further down whereas it would probably have allowed them to reach another seam but they fell back on the first seam which was exploited on $22 \mathrm{~m}^{2}$ (Collet \& Van Neer 2002). As in the mines discussed above, the raw material was subjected to a severe selection right after extraction as evidenced by several tons of abandoned flint in the underground mining waste of the ST11 shaft.

These mines belong to the Late Neolithic. Shaft 80.4 was dated from 3350 to 3030 years BCE (Table $1 \mathrm{nr}$ 29); ST11 shaft was dated from 3500 to 3100 years BCE (Table $1 \mathrm{nr} 23$ and $\mathrm{nr} 24)$. They are located in the same zone as the mines discussed above, where the flint of the second and third seams was exploited, an area already heavily mined during the Middle Neolithic. The extended exploitation of the first seam appears here as a second choice, dictated by the special conditions occasioned by the presence of older mines in the same sector.

\subsection{Very deep mining in Camp-à-Cayaux}

The most sophisticated mining techniques implemented on the site were identified in the heart of Camp-à-Cayaux. Deep shafts, of about $1 \mathrm{~m}$ diameter and widening at the base to form a small room, were dug up to 15 and $16 \mathrm{~m}$ deep to extract large flint slabs in low galleries (Hubert 1978). The depth of these galleries is explained by the miners' selection of a specific seam composed of large tabular flint. No mine exploiting this exceptional raw material at shallow depth is known to date. But given the dip of the seam it should outcrop some $50 \mathrm{~m}$ to the east and, theoretically, shallower pits could be discovered there. To reach these slabs the miners dug through about 15 flint seams, which were not exploited (Figure 19). Once at the right depth, they found two very close tabular flint seams of which only the lowest, the 17th, was exploited. The upper one was left untouched in the roof of the galleries. The reason why straighten the roof? - is still open to question. Flint slabs weighing up to 500 kilos were pulled down from the roof of the galleries. The height of these galleries not exceeding 0.8 to $1 \mathrm{~m}$ once the slab was removed, the miners had to work in very confined spaces, often not more than $50 \mathrm{~cm}$ high (Figures 20 and 21). François Hubert, the archaeologist who studied these mines in detail, supposed that to extract these slabs, the miners resorted to the 'caving technique'. They had to dig underneath the seam, gradually removing the chalk holding the slab. To avoid the slab falling on them while mining, they probably used wooden shores. Once the slab was loosened enough they removed the shores and it would collapse under its own weight (Hubert 1978: 17). Later excavations led to the discovery of remnants of chalk walls in the axis of the removed slabs that could have been left under the flint block to hold it in place while the wooden shores were installed (Hubert 1983; 1990). Overall, each of these mines allowed the exploitation of 40 to $50 \mathrm{~m}^{2}$ underground, which made it possible to extract about thirty slabs. 


\section{Om}

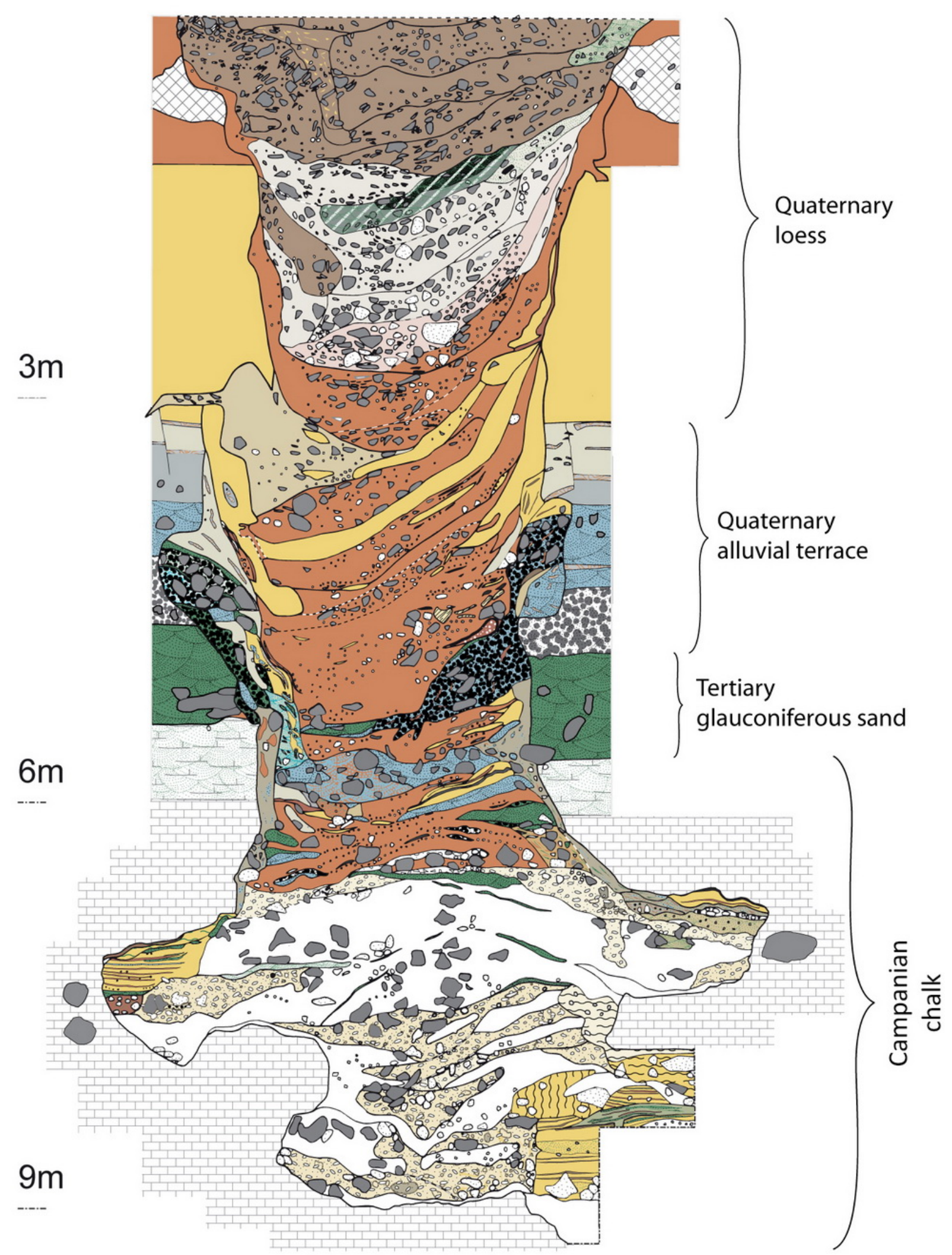

Figure 18. Petit-Spiennes. ST11 mining shaft (excavations 1997-1999). Graphics by M. Woodbury, SPW. 


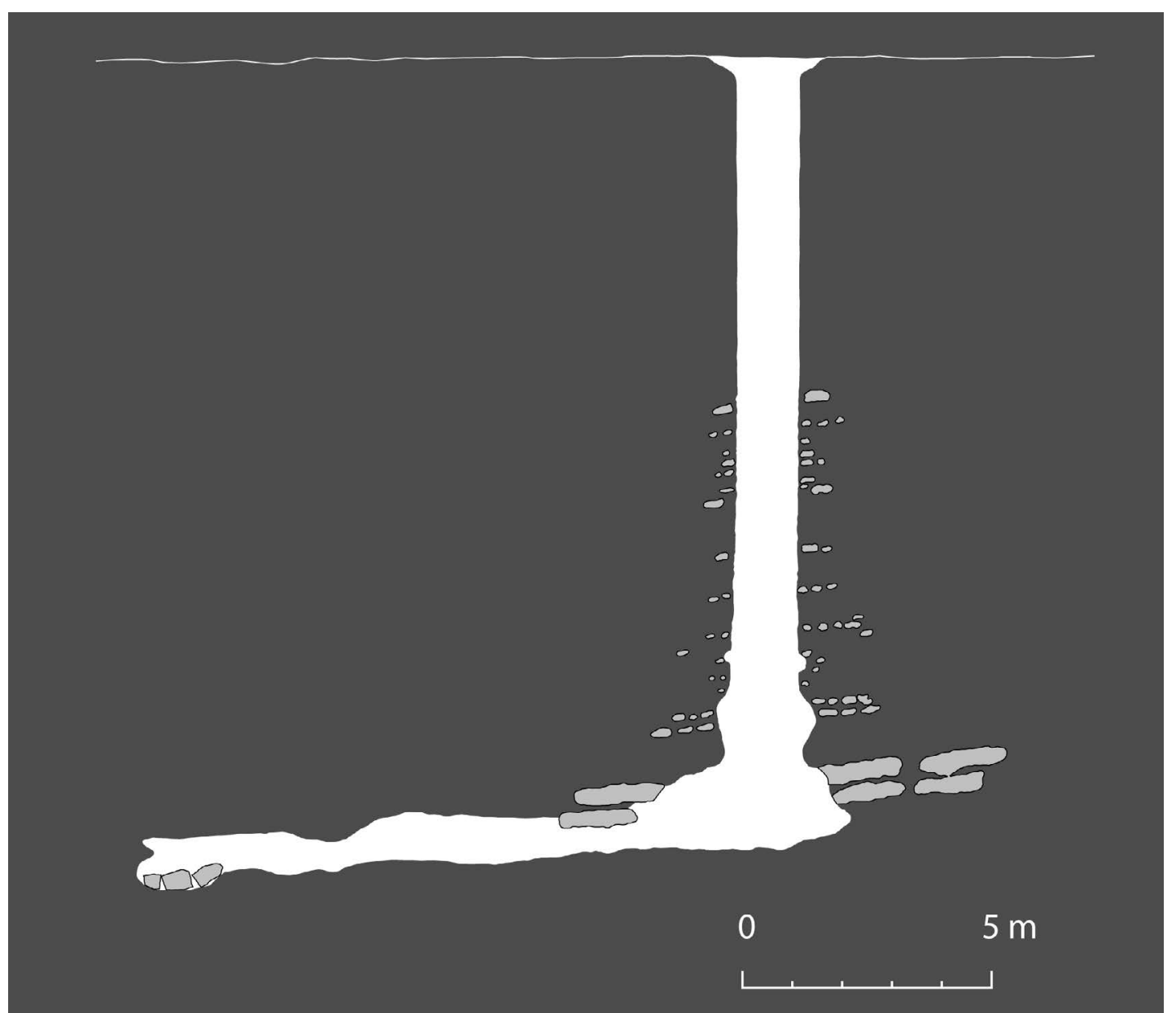

Figure 19. Spiennes, Camp-à-Cayaux. Flint mining shaft nr 2 (excavations 1912-1914). Graphics y M. Woodbury, SPW modified after Hubert (1978).

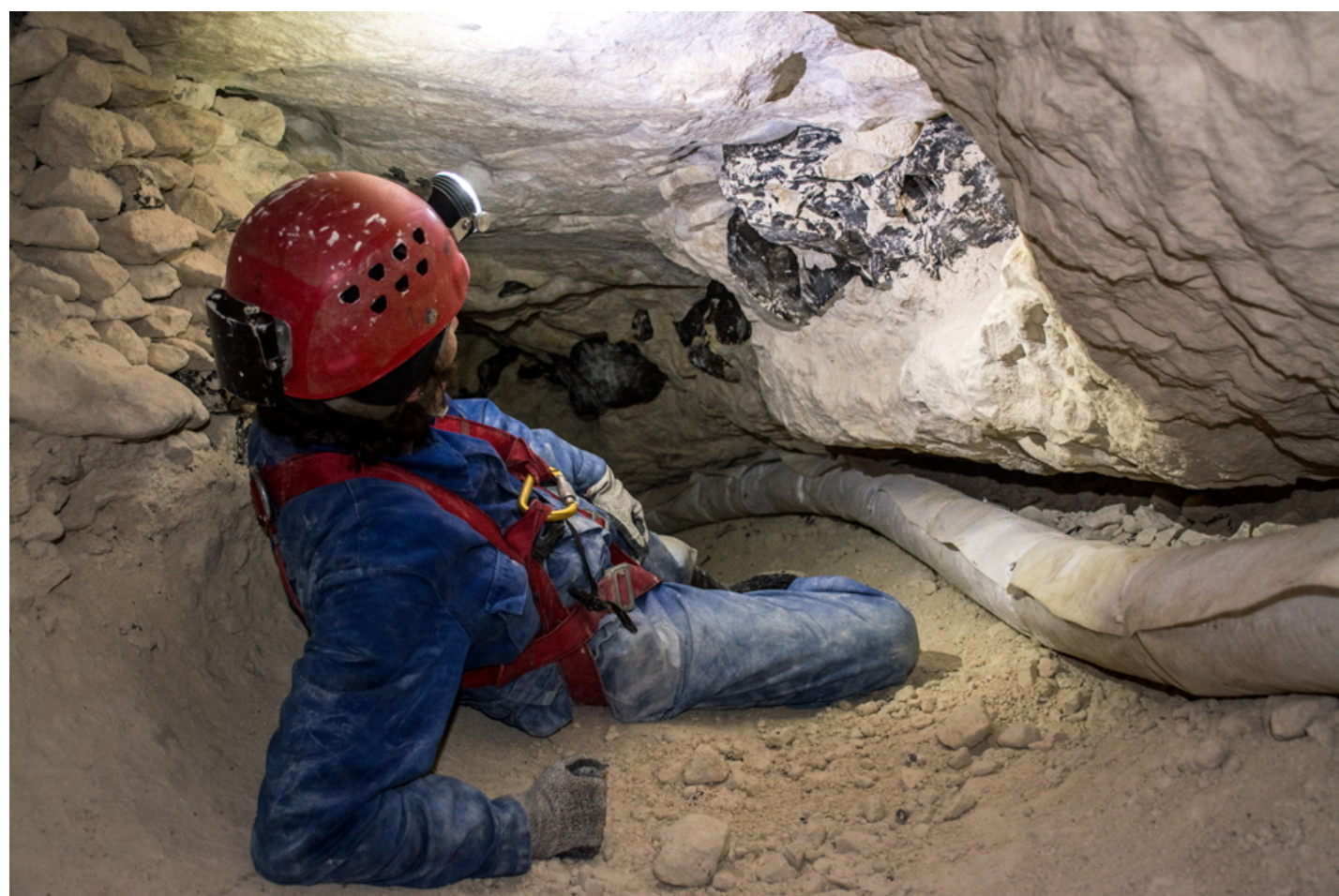

Figure 20. Spiennes, Camp-à-Cayaux. Extraction gallery, east of shaft nr 1 (excavations 1912-1914). Photo by M. Woodbury, SPW. 


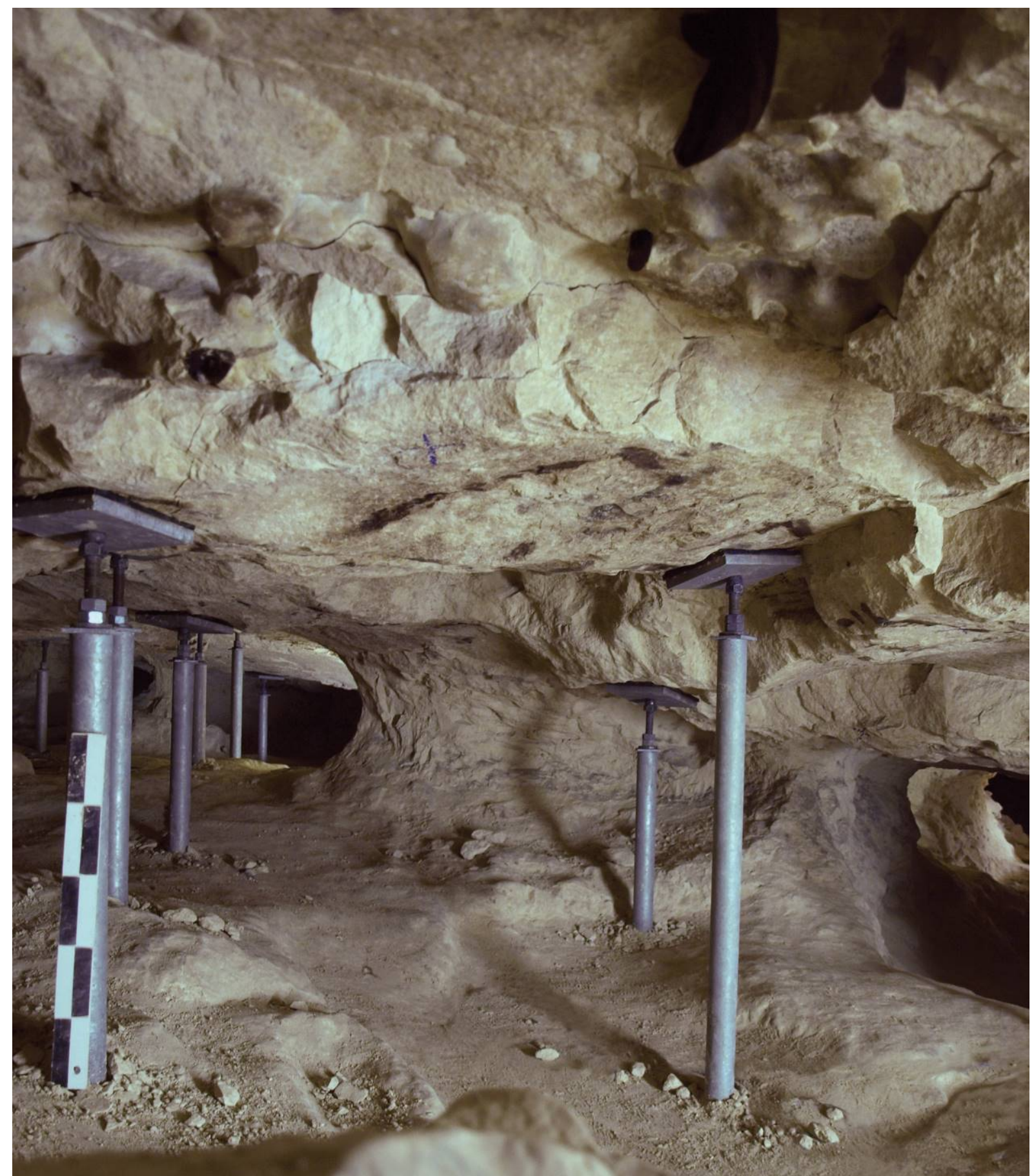

Figure 21. Spiennes, Camp-à-Cayaux. Extraction gallery (1912-1914 excavations). Photo D. Werra, IAEPAN.

It should be noted that a similar caving technique, a formidable technical feat given the size of the blocks, was used in other Neolithic flint mines such in Mine 1 of La Defensola A and the mines of La Defensola B, in Italy (Tarantini \& Galiberti 2011). It was also used to extract smaller nodules in other sites, such as in the 'bell-shaped' mines of Jablines (Bostyn \& Lanchon 1992) and some mines in Rijckholt-St. Geertruid (Felder 1998). In other mines, though, tabular flint nodules were systematically extracted either half-height of the galleries or at the base such as in Krzemionki Opatowskie (Poland) and Grime's Graves (United Kingdom). No equivalent of the technique that, in Spiennes, consists in leaving a seam untouched in the roof of the galleries is known, which is surprising. 
The depth of the mines, combined with the narrowness of the shafts, undoubtedly constituted a challenge in terms of ventilation and lighting. Studies for the monitoring of the mines recently undertaken both in Camp-à-Cayaux and Petit-Spiennes in view of the conservation of the site showed that, during part of the year, air renewal is problematic even in the shallower mines. This lack of natural ventilation occurs each time the external temperature is higher to that of the underground and no convection is possible, or between May and October. In these conditions the level of Carbon Dioxyde rises quickly and it accumulates underground (Verstraelen 2015: 17-18). The problem is even worse in the deep mining shafts of Camp-à-Cayaux. The digging of pairs of shafts very close to one another in Camp-à-Cayaux, a device known to trigger underground ventilation, could have been a solution to that problem (Figure 22, shafts 2 and 3; shafts 1 and 4). In Rijckholt-St. Geertruid as well, the archaeologists pointed to the existence of galleries left empty at all times, linking two shafts that were operating simultaneously. They considered it as an escape gallery for the safety of the miners but also underlined the benefit in terms of ventilation of such a device (Felder et al. 1998).

Data relating to lighting in the deep mines of Camp-à-Cayaux are completely lacking but it should be reminded that they were excavated at the start of the 20th century and that the early archaeologists could have missed the evidence. Although the need for artificial lighting appears obvious, the material collected underground does not include any lighting device. Artefacts interpreted as 'lamps' were found at the surface in Camp-à-Cayaux (Verheyleweghen 1958) but the context of discovery is doubtful.

The deep mines in Camp-à-Cayaux were first attributed to the Michelsberg period on basis of pottery fragments (Hubert 1978). Recently a radiocarbon date of 4230-3940 cal BCE (Figure $\mathrm{nr} 3$ ) confirmed the attribution and revealed that these very sophisticated extraction structures were among the oldest of the site (Collet et al. 2012).

\section{Discussion}

\subsection{Flint mining strategy}

The analysis of the mining techniques implemented by the miners of Spiennes for flint extraction both in Petit-Spiennes and Camp-à-Cayaux, related to the specific lithic productions of the mines, clearly demonstrate a quest for quality raw material, suitable for their technical needs.

The characteristics of the end products of the knapping workshops of Spiennes are very specific: they consist essentially in large axeheads (up to $28 \mathrm{~cm}$ long) and robust blades (15 to $20 \mathrm{~cm}$ long). They also present a high degree of standardisation. This necessitates large flint nodules or slabs of good knapping quality. It seems that the mining techniques identified in Spiennes were implemented to select precisely that type of raw material.

The selection of a specific seam - sometimes deeply buried - or of a particular raw material is a characteristic shared by many mining sites even if it is not a constant feature. Indeed, for some of them as at Mesnil-Saint-Loup (Aube, France), only the most accessible flint nodules were extracted. Mining structures consist in mere extraction pits because, given the unstable bedrock, digging deep shafts might have been dangerous (Hauzeur et al. 2010).

Raw material selection is clearly guided by material considerations: the search for quality flint suitable for the lithic products the knappers had in mind. Raw material can be valued by the miners for its knapping qualities, for the suitability of its morphology and dimensions and for its quantity available. At Jablines, the miners almost systematically neglected the topmost seam and chose to extract the second encountered. At first sight the two seams appear to be equivalent, however, only the second one is knappable. Indeed the flint tablets of the topmost 
seam present defaults which cause uncontrolled shatter during the knapping process (Bostyn \& Lanchon 1992: 40). At Rijckholt St. Geertruid, in mining shafts that could reach $14 \mathrm{~m}$ deep, seam nr 10 was preferably exploited. Containing fair size nodules it is actually the first quality seam reached by the miners in these shafts. Indeed the upper seams (11 to 20) comprise only a small proportion of knappable flint (Felder et al. 1998). In Grime's Graves, the third seam known as 'floor stone' has qualities undoubtedly superior to the first two seams reached in the shafts. It takes the form of large tabular flint blocks of $15 \mathrm{~cm}$ thick while the first two seams (topstone and wallstone) are poorer and comprise irregular and weathered nodules (Mercer 1972).

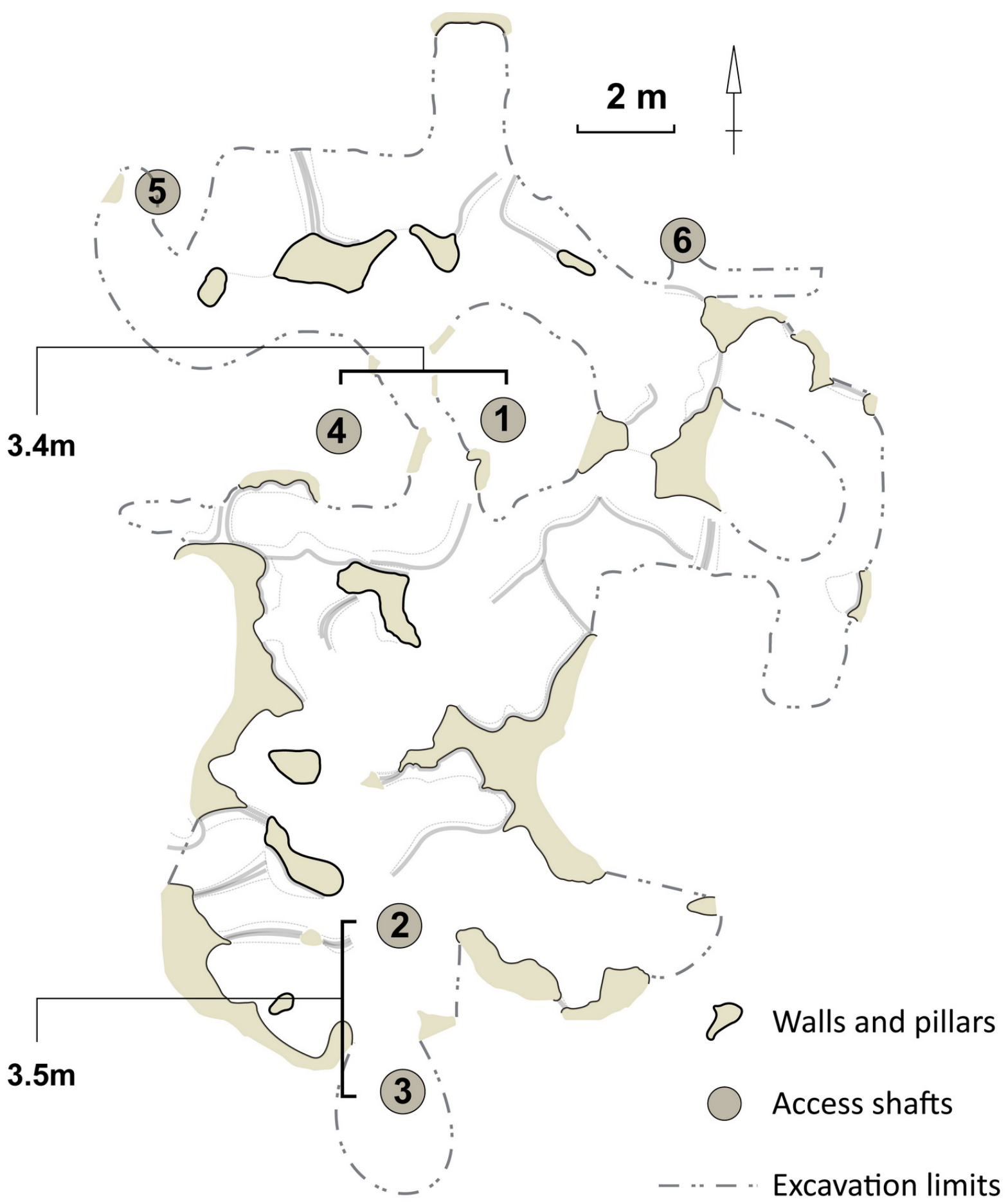

Figure 22. Spiennes, Camp-à-Cayaux. Underground map of the $16 \mathrm{~m}$ deep mines (excavations 1912-1914). Graphics by M. Woodbury after Hubert (1978), SPW. 
At Spiennes, in the deep shafts of Camp-à-Cayaux, the large size of the slabs and their very regular shape could have been the motivation behind the digging of such deep structures. Indeed these huge blocks obviously facilitated the shaping of cores for the mass production of long blades (Figures 23 and 24). By comparison, the nodules extracted at Petit-Spiennes did not offer the same possibilities in terms of blade production. As a matter of fact, blade production is mostly attested in the Camp-à-Cayaux mining zone. It is the only place on the site where all the stages of the chaîne opératoire are present, from the pre-shaped blocks to the blades, including the exhausted blade cores and the crest blades, evidence of a local blade production (Colman 1957; Hubert 1969). Recent excavations undertaken in the immediate vicinity of the deep mines showed that the blade content is indeed present in the associated industry (Collet \& Woodbury 2008). The discovery of an exhausted blade core (Figure 25) (Hubert 1983) and numerous blade cores reused as picks in the underground mining waste of one of these $16 \mathrm{~m}$ deep shafts further underlines the link between the extraction of the huge slabs and blade production (Hubert 1983). On the other hand, in Petit-Spiennes where only smaller nodules were exploited, the only evidence of on-site blade production is the presence of exhausted blade cores recycled as picks. Indeed, depending on the structure, between 4 and $16 \%$ of the mining picks where shaped out of abandoned blade cores. The backfills of the access shafts yielded some exhausted blade cores but no other artefacts resulting from blade production (crest blades, blades). It is thus not unlikely that these cores were transported from another location (from Camp-à-Cayaux? from elsewhere in Petit-Spiennes?) to be recycled near the shafts. Indeed the latest excavations of both shafts and knapping workshops revealed that in Petit-Spiennes most of the lithic industry was oriented toward the production of bifacial tools - mostly axeheads (Figure 26) but also chisels (Collet 2012; Collet et al. 2014). In the Versant de la Wampe mining zone, only the bifacial knapping technique is attested in the backfills of the shafts. Lastly, it must be reminded that flint extracted from the Camp-àCayaux mining zone was not used exclusively for blade production. Indeed the production of bifacial tools such as axeheads and chisels - among which examples of very large size - is also well represented (Figure 27).

If the targeting of specific flint seams seems clearly related to the characteristics of the end products the miners or knappers had in mind, other mining techniques are not interpreted as easily, as their functional purpose is far from obvious.

For instance, the higher profitability (the ratio of raw material collected compared to the amount of sterile rock excavated) of deep mines of Camp-à-Cayaux was emphasized by some researchers. Compared to the shallower mines where nodular flint seams were exploited in Petit-Spiennes, where flint amounts to a mere $8 \%$ of the total volume of sediments and bedrock excavated, the deep mines of Camp-à-Cayaux produced 22\% of flint (Hubert 1978).

Surprisingly, in the deep shafts of Camp-à-Cayaux, the upper tabular seam - the 16th was left untouched in the roof of the galleries by the miners. There seem to be no equivalent in other Neolithic flint mines in Europe. If the profitability of a mine was an important consideration for Neolithic miners, why did they neglect the 16th seam as it would have doubled the profitability of the mines? François Hubert (1978) thinks that the slabs were left in place to shore up the roof of the galleries but this point should be verified in the future as other explanations are equally possible (e.g., difficulty of extracting the upper seam in the same galleries? insufficient knapping qualities? etc.). 

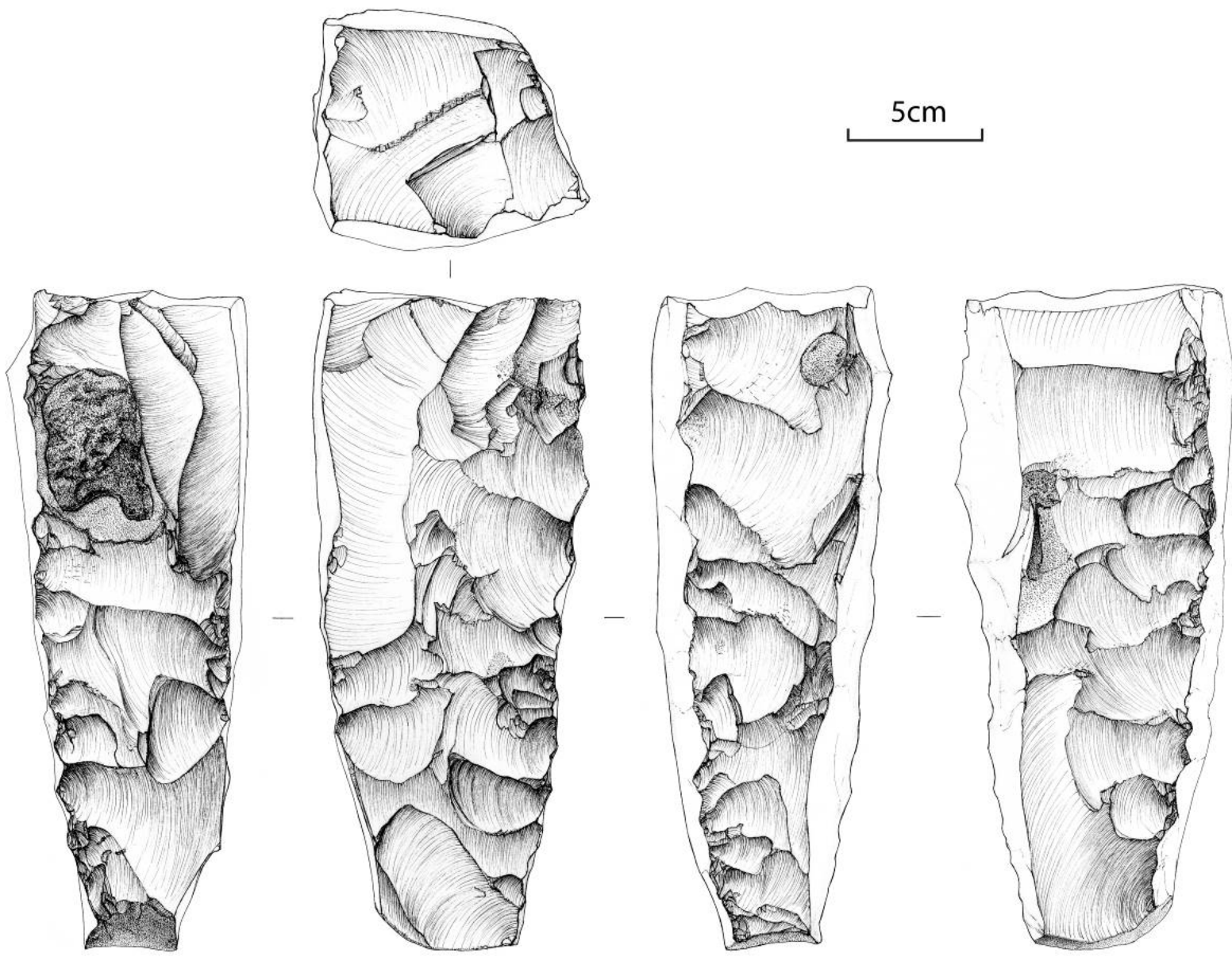

Figure 23. Spiennes, Camp-à-Cayaux. Blade core abandoned at the stage of shaping. L. Desailly Collection, UMons. Drawing by A.-M. Wittek, ADIA (Association pour la Diffusion de l’Information Archéologique).

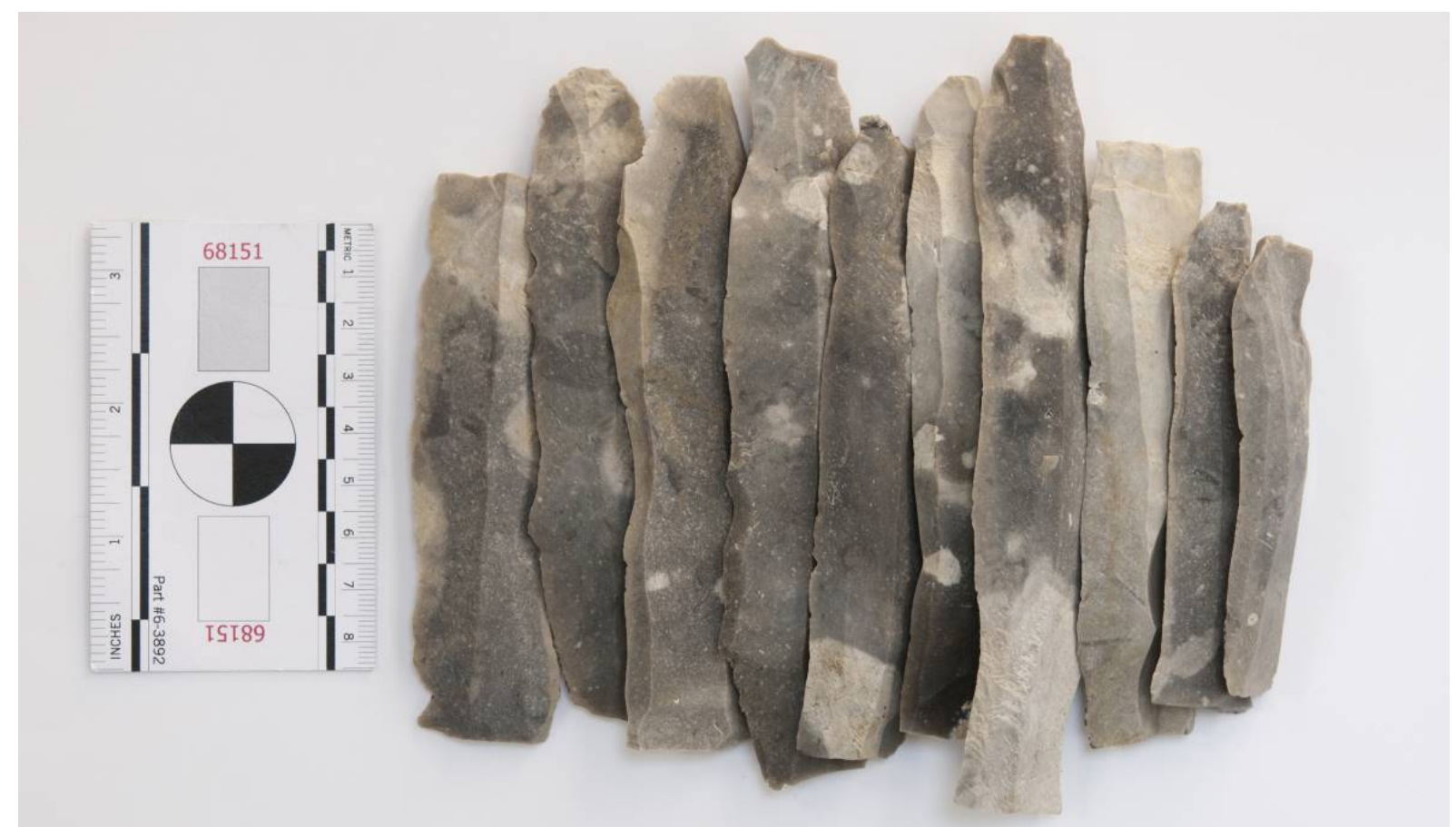

Figure 24. Spiennes, Camp-à-Cayaux. Flint blades abandoned on the mining site (1965 excavations by F. Hubert). Photo by M. Woodbury, SPW. 

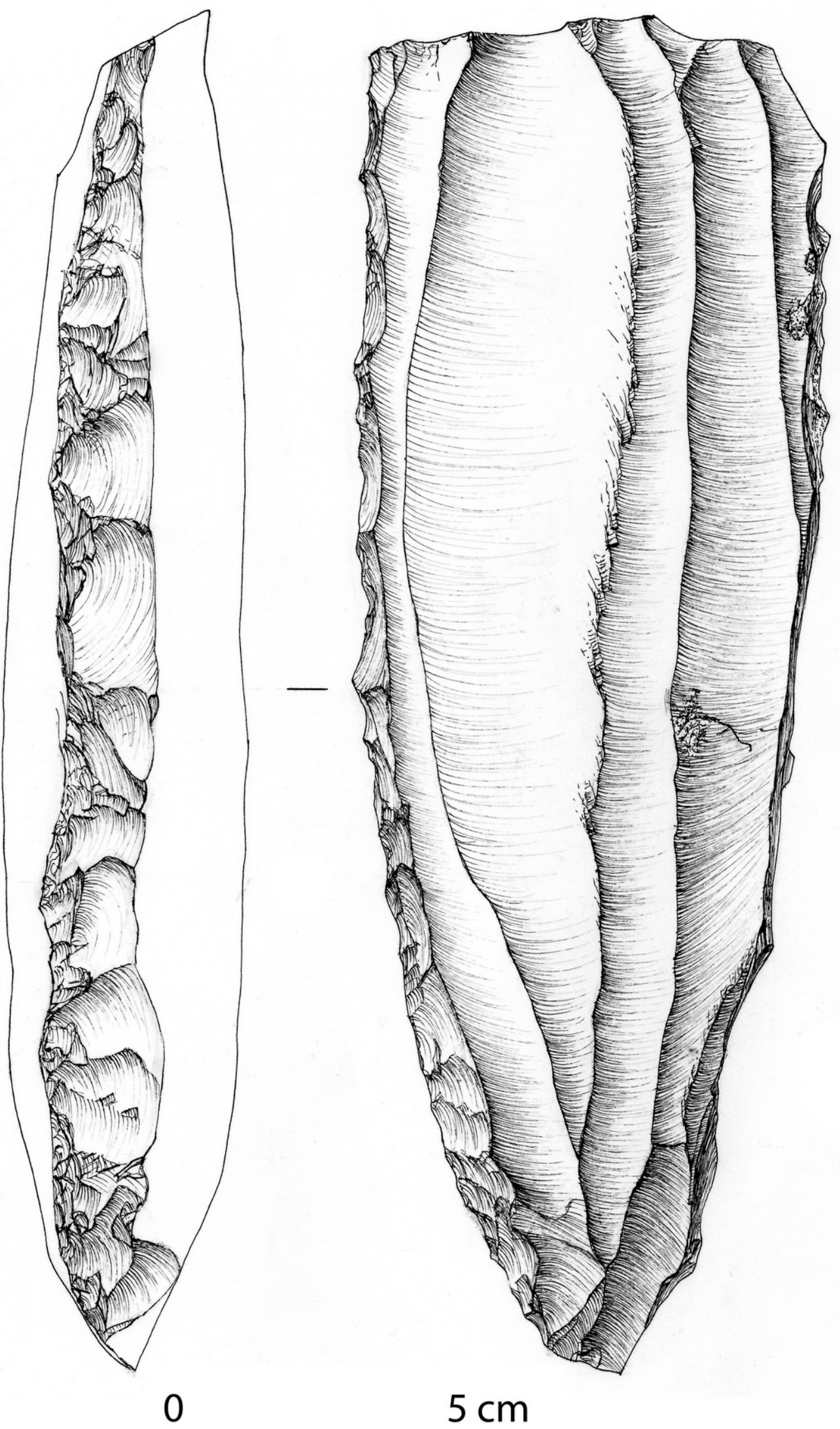

Figure 25. Spiennes, Camp-à-Cayaux. Exhausted blade core, found at the bottom of the deep mines (1982 excavations by F. Hubert). Drawing by A.-M. Wittek, ADIA (Association pour la Diffusion de l'Information Archéologique). 


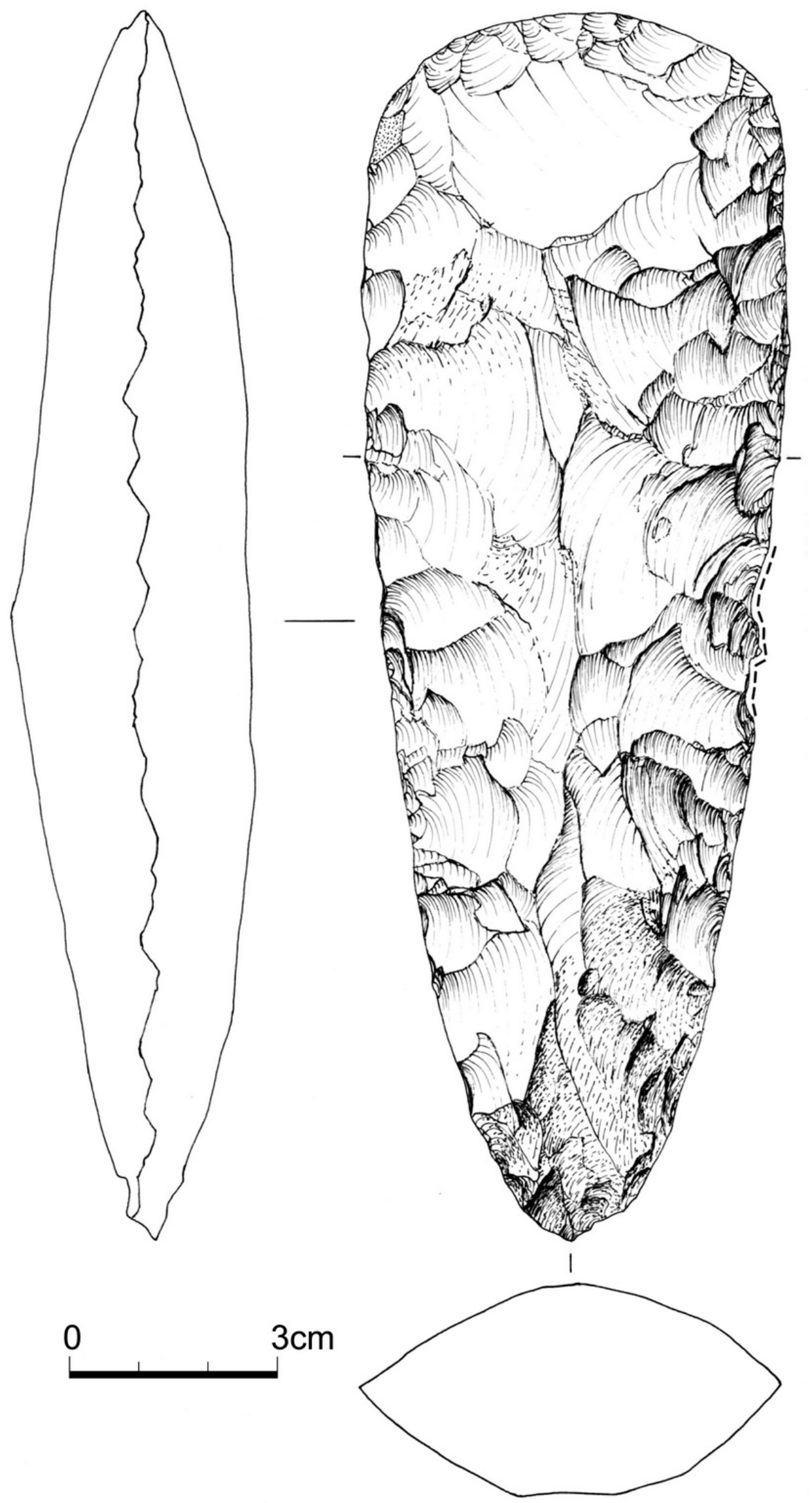

Figure 26. Petit-Spiennes. Flaked axehead (ST 20 shaft). Drawing by A.-M. Wittek, ADIA. 


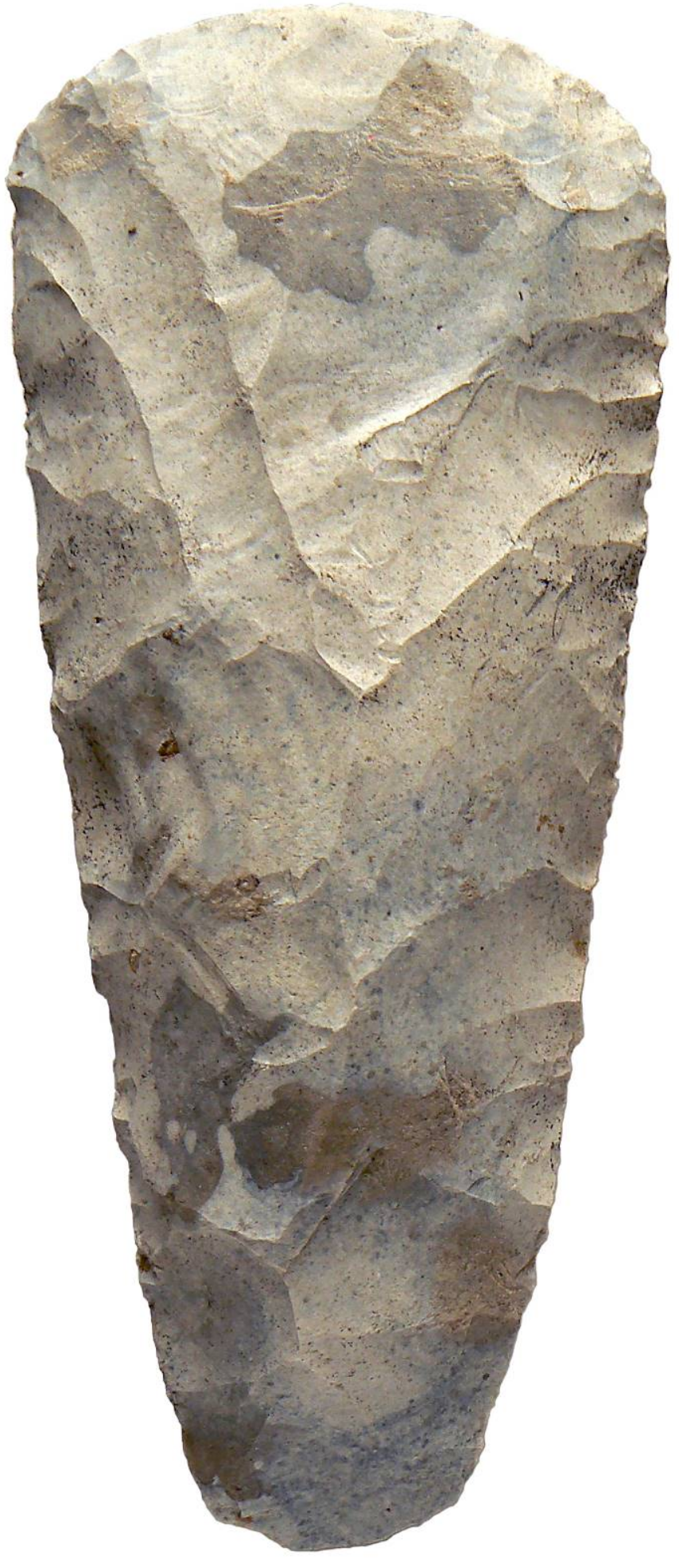

0

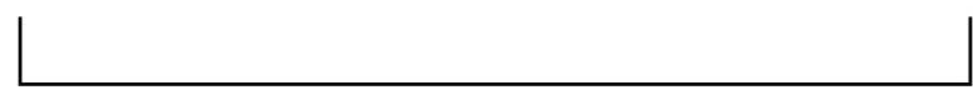

Figure 27. Spiennes, Camp-à-Cayaux. Flaked axeheads (surface knapping workshop, near the deep mines). Photo by M. Woodbury, SPW. 


\subsection{Social organisation of mining}

Although Spiennes was still in activity in the Late Neolithic most of the dates available and the best known structures pertain to the Middle Neolithic, at a time when an enclosed settlement was installed on the Petit-Spiennes plateau (see above 4. Social context). This suggests a close control of the mines during the Michelsberg period by the local population. However, the way village life articulated with flint mining is not clearly established yet. What is certain is that mining activities, as well as the production of the specific highly standardised tools linked to the mines, certainly necessitated a real know-how that could have concentrated in the hands of the local population.

The duration of activity of each mine has been estimated, essentially on basis of the analysis of the chalk mining waste stratigraphy, to a few months maximum, or a single season. Indeed there is no trace, in the mining layers, of runoff phases that may indicate an interruption of work while the access shaft was still open. The period of the year during which mining work took place is not known yet for certain, however, to avoid ventilation problems, the best season would have been winter. Winter is also the slow period for farm work. We know that the human groups who exploited the mines were first and foremost farmers. Given the limited technical resource at their disposition, it is unlikely that a part of the village population could abstain from participating in farming activities. Last but not least, traces of interruption phases during the backfilling of the shafts were identified and could correspond to interruptions of mining work (Collet \& Van Neer 2002). All in all, there is definitely some evidence pointing to a seasonal organisation of mining activities. As a matter of fact, Spiennes is not the only European mining site where seasonality is considered likely, as G. Roth came to the same conclusions for the Arnhofen mines in Germany (Roth 2008). Peter Topping (2011) found other seasonal clues for the British mines pointing to spring or summer mining activity. Future field research will hopefully bring more data to discuss the issue.

Before concluding we have to stress that the exploitation of the mines during the Middle and Late Neolithic was certainly accompanied by ritual and magical practices both expressing community ties and supposed to affect the outcome of the undertakings. It has to be said, however, that such issues are by nature very difficult to decipher.

The flint mines of Spiennes are certainly no exception. It is in this regard that we probably have to understand the burials introduced in the backfills of the shafts a short time after the mines were abandoned. While isolated human bones discovered during older archaeological excavations are difficult to interpret, modern research yielded three complete skeletons the study of which is underway (Collet \& Toussaint 1998; Lavachery et al. 2015).

\section{Conclusion}

Combining data from 150 years of archaeological research, including excavations that are still underway, the strategy of raw material acquisition implemented on the flint mines of Spiennes becomes clearer. Michelsberg miners were first and foremost farmers, but living close to a hugely rich flint deposit, were able to develop sometimes complex mining techniques to reach specific flint seams, deemed adequate for the production of standardised axeheads and blades. It is most probable that these specialised endeavours were conducted only during winter, the period of the year when farming activities were slow and ventilation in the mines was optimal. Century-old traditions, group specialisation in mining and knapping and close social control of flint resources allowed the mines to be in activity during 1500 years and to dominate the raw material supply of the Mons Basin for centuries. 


\section{References}

Allard, P., Bostyn, F. \& Martial, E. in collaboration with Collet, H., Fabre, J. \& Vallin, L. 2010, Les matières premières siliceuses exploitées au Néolithique moyen et final dans le nord de la France et la Picardie (France). In: Premiers Néolithiques de l'Ouest. Cultures, réseaux, échanges des premières sociétés néolithiques à leur expansion (Billard, C. \& Legris, M., Eds), Actes du colloque interrégional sur le Néolithique du Havre, Presses universitaires de Rennes, Rennes: p. 347-375. (in French) (“The siliceous raw materials exploited in the Middle and Final Neolithic in the North and Picardy (France)") URL: https://www.academia.edu/4277499/

Bostyn, F. \& Collet, H. 2011, Diffusion du silex de Spiennes et du silex Bartonien du Bassin parisien dans le Nord de la France et en Belgique de la fin du 5e millénaire au début du 4e millénaire $\mathrm{BC}$ : Une première approche. Revue archéologique de Picardie. (Le Néolithique du Nord de la France dans son contexte européen: Habitat et économie aux $4 e$ et 3e millénaires avant notre ère Bostyn, F., Martial, E. \& Praud, I., Eds), 28 (special issue): 331-347. (in French) ("Diffusion of Spiennes flint and Bartonian flint from the Paris Basin in the North of France and Belgium: A first approach”) doi:10.3406/pica.2011.33399

Bostyn, F. \& Lanchon, Y., Eds 1992, Jablines “Le Haut Château” (Seine-et-Marne). Une minière de silex au Néolithique. Documents d'archéologie française. Vol. 35. Collection Archéologie et Grands Travaux. Éditions de la Maison des Sciences de l'Homme, Paris, 246 p. (in French) (“Jablines 'Le Haut Château’ (Seine-et-Marne). A Neolithic flint mine”)

Briart, A., Cornet, F. \& Houzeau de Lehaie, A. 1868, Rapport sur les découvertes géologiques et archéologiques faites à Spiennes en 1867. Mémoires et publications de la Société des Sciences, des Arts et des Lettres du Hainaut, année 1866-1867, 3(2): 355-398. (in French) ("Report on the geological and archaeological discoveries made at Spiennes in 1867”)

Bronk Ramsey, C. 2005, OxCal Program v3.10. Manual. University of Oxford Radiocarbon Accelerator Unit, Oxford. Retrieved 15 January 2016. URL: https://c14.arch.ox.ac.uk/oxcal3/oxcal.htm

Clason, A. T. 1981, The Flintminers as a Farmer, Hunter and Antler Collector. Staringia (Derde internationale symposium over vuursteen. 24-27 mai 1979, Heerlen. Engelen, F.H.G., Ed), 6: 119-125.

URL: http://natuurtijdschriften.nl/download?type=document;docid=568111

Collet, H. 2000, Fouille de nouveaux puits d'extraction à Petit-Spiennes et découverte de fragments de polissoir. Notae Praehistoricae, 20: 163-170. (in French) ("Excavation of new mining shafts at Spiennes and discovery of polissoir fragments”)

Collet, H. 2012, La production de haches à Spiennes: Un état de la question. In: Produire des haches au Néolithique: De la matière première à l'abandon. Actes de la Table ronde de Saint-Germain-en-Laye (de Labriffe, P.-A. \& Thirault, E., Eds), Séances de la Société Préhistorique Française Vol. 1, Société préhistorique française, Paris: p. 139-148. (in French) (“Axe production in Spiennes: A status report”) URL: http://www.minesdespiennes.org/blog/wp-content/uploads/2014/05/Collet2012.pdf 
Collet, H., Hauzeur, A. \& Lech, J. 2008, The prehistoric flint mining complex at Spiennes (Belgium) on the occasion of its discovery 140 years ago. In: Flint mining in Prehistoric Europe: Interpreting the archaeological records (Allard, P., Bostyn, F., Giligny, F. \& Lech, J., Eds), European Association of Archaeologists, 12th Annual Meeting, Cracow, Poland, 19th-24th September 2006, British Archaeological Reports International Series Vol. 1891. Archaeopress, Oxford: p. 41-77.

URL: http://minesdespiennes.org/textes/Collet_Hauzeur_Lech2008.pdf

Collet, H., Jadin, I. \& Toussaint, M. 2012, Mons/Spiennes: Datation des puits profonds des minières du "Camp-à-Cayaux" de Spiennes. Chronique de l'Archéologie wallonne, 19: 62-63. (in French) ("Mons/Spiennes: Dating of the deep mining shafts of Camp-àCayaux”)

URL: http://spw.wallonie.be/dgo4/tinymvc/apps/caw/views/documents/flippingBook/C AW19/CAW19/assets/basic-html/page63.html

Collet, H. \& Toussaint, M. 1998, Découverte d'un squelette humain néolithique sur le site minier de Petit-Spiennes (Hainaut, Belgique): Étude préliminaire, Actes de la Journée d'information du 14 novembre 1998. Internéo Vol. 2, Société préhistorique française, Paris: p. 113-124. (in French) ("Discovery of a Neolithic human skeleton on the PetitSpiennes flint mining site (Hainaut, Belgium): Preliminary study”)

Collet H., Vanmontfort B. \& Jadin I. In collaboration with F. Hubert 2011, Des pots dans les mines. La céramique Michelsberg des minières et de l'enceinte du site de Spiennes (Hainaut, Belgique). Revue archéologique de Picardie. (Le Néolithique du Nord de la France dans son contexte européen: Habitat et économie aux 4e et 3e millénaires avant notre ère Bostyn, F., Martial, E. \& Praud, I., Eds), 28(special issue): 167-181. doi:10.3406/pica.2011.3329

Collet, H. \& Van Neer, W. 2002, Stratigraphie et faune d'un puits d'extraction néolithique à Petit-Spiennes. Anthropologica et Praehistorica, 113: 73-104. (in French) ("Stratigraphy and fauna of a Neolithic mining shaft at Petit-Spiennes") URL: https://www.academia.edu/2257855/

Collet, H. \& Woodbury, M. 2006, Mons/Spiennes: Poursuite des fouilles dans la parcelle 393 de «Petit-Spiennes». Chronique de l'Archéologie wallonne, 13: 47-48. (in French) ("Mons/Spiennes: Continuing excavations on parcel 393c at "Petit-Spiennes"”)

Collet, H. \& Woodbury, M. 2007a, Mons/Spiennes: Découverte de vestiges d’époque indéterminée rue du Moulin. Chronique de l’Archéologie wallonne, 14: 83. (in French) ("Mons/Spiennes: Discovery of remains of unknown age at Rue du Moulin”) URL: http://docum1.wallonie.be/DOCUMENTS/CAW/14/83.pdf

Collet, H. \& Woodbury, M. 2007b, Etude et caractérisation des déchets lithiques abandonnés dans les niveaux d'exploitation de la minière ST 20 de Petit-Spiennes (Province de Hainaut). Notae Praehistoricae, 27: 151-122. (in French) ("Study and characterisation of the flint waste abandoned in the mining levels of ST 20 shaft at Petit-Spiennes (Hainaut Province)") URL: http://www.naturalsciences.be/mars/groups/fnrs-contactgroup/notae-praehistoricae/notae-praehistoricae-27-2007 
Collet H. \& Woodbury M., 2008, Mons/Spiennes: Fouille préventive des abords du Centre de Recherches archéologiques, anciennement appelé musée du «Champ-à-Cailloux». Chronique de l'Archéologie wallonne, 15: 35-37. (in French) ("Development-led excavation of the surroundings of the Archaeological Research Centre, previously named 'Champ-à-Cailloux'Museum”)

URL: http://spw.wallonie.be/dgo4/tinymvc/apps/caw/views/documents/flippingBook/C AW15/CAW15/assets/basic-html/page37.html

Collet, H. \& Woodbury, M. 2010, Mons/Spiennes: Suivi archéologique des travaux d'aménagement de la SWDE rue de Nouvelles et chemin de Spiennes. Chronique de l'Archéologie wallonne, 17: 52-53. (in French) ("Archaeological monitoring of the SWDE works at Rue Nouvelles and Chemin de Spiennes")

URL: http://spw.wallonie.be/dgo4/tinymvc/apps/caw/views/documents/flippingBook/C AW17/CAW17/assets/basic-html/page53.html

Collet, H., Woodbury, M. \& Collin, J.-Ph. 2014, Investigation of new chipping floors at the flint mining site of Spiennes (Hainaut Province, Belgium) in 2011 and 2012. In: Lithic raw Material Resources and Procurement in Pre- and Protohistoric Times: Proceedings of the $5^{\text {th }}$ International Conference of the UISPP Commission on Flint Mining in Preand Protohistoric Times, Paris 10-11 September 2012 (Bostyn, F. \& F. Giligny, F., Eds), British Archaeological Reports International Series Vol. 2656, Archaeopress, Oxford: p. 47-58.

Collin, J.-Ph. 2016, Mining for a week or for centuries: Variable aims of flint extraction sites from the Mons Basin in the lithic economy during the Neolithic (Prov. of Hainaut, Belgium). Journal of Lithic Studies, 3(2): 163-179. doi:10.2218/jls.v3i2.1819

Colman, P. 1957, Le Néolithique et ses prolongements à Spiennes. Bulletin de la Société royale belge d'Études géologiques et archéologiques "Les Chercheurs de la Wallonie", 16: 226-290. (in French) ("The Neolithic period and its development in Spiennes")

Felder, P.J.S. 1998, Interpretaties van de plattegronden in het onderzochte mijngebied. In: De prehistorische vuursteenmijnen van Ryckholt-St. Geertruid (Rademakers, P.C.M. Ed), Nederlandse Geologische Vereniging, Afdeling Limburg, Beek: p. 277-282. (in Dutch) ("Interpretation of the maps of the excavated mining field")

Felder, P.J.S., Rademakers, P.C.M. \& de Grooth, M.E.TH 1998, Excavations of Prehistoric Flint mines at Rijckholt-St. Geertruid (Limburg, The Netherlands), Archäeologische Berichte, 12, Deutsche Gesellschaft für Ur- und Frühgeschichte, Bonn, 85 p.

Giligny, F., Bostyn, F. \& Le Maux, N. 2012, Production et importation de haches polies dans le Bassin parisien: Typologie, chronologie et influences. In: Jades. Grandes haches alpines du Néolithique européen. Ve et IVe millénaires av. J.-C. Vol. 2 (Pétrequin, P., Cassen, S., Errera, M., Klassen, L., Sheridan, A. \& Pétrequin, A.-M., Eds), Presses universitaires de Franche-Comté, Besançon: p. 1136-1167. (in French) ("The production and importation of polished axes in the Paris basin: Typology, chronology and influences”) URL: https://www.researchgate.net/publication/282576878

Goffette, Q., Salavert, A. \& Court-Picon, M. 2014, Tirer parti de tous les vestiges: Os, coquilles, charbons, graines, pollens et spores. In: Les minières néolithiques de silex de Spiennes. Patrimoine mondial de l'Humanité. (Collet, H., Ed), Institut du Patrimoine wallon, Namur: p. 39. (in French) ("Taking account of all the evidence: bones, snails, charcoals, grains, pollen and spores”) 
Gosselin, F. 1986, Un site d'exploitation du silex à Spiennes (Hainaut), au lieu-dit "PetitSpiennes”. Vie archéologique, 22: 33-160. (in French) (“A flint mining site at Spiennes (Hainaut)”) URL: http://www.minesdespiennes.org/textes/spiennes.Gosselin1986_lt2.pdf

Gosselin, F. 1990, Potentiel archéologique de Spiennes. In: Etude préalable à la sauvegarde et à la mise en valeur du site archéologique de Spiennes - Mons (Centre archéologique de Recherche minière, Ed), Centre archéologique de Recherche minière, Spiennes: p. 647. (in French) (“The archaeological potential of Spiennes")

Haesaerts, P. 1984, Les formations fluviatiles pléistocènes du bassin de la Haine (Belgique). Bulletin de l'Association française pour l'étude du Quaternaire, 21(1-3): 19-26. (in French) ("Pleistocene fluvial formations in the Haine Basin (Belgium)") doi:10.3406/quate.1984.1474

Hauzeur, A., Collin, J.-Ph., Naton, G.-H., Bernard-Guelle, S. \& Fernandes, P. 2010, Un site d'exploitation néolithique dans le complexe minier du Pays d'Othe: Fouille préventive à Mesnil-Saint-Loup - «Les Vieilles Vignes» (Aube, France). Notae Praehistoricae, 30: 57-71. (in French) ("A Neolithic mining site in the mining complex of the Pays d'Othe (Aube, France)”) URL: http://www.naturalsciences.be/mars/groups/fnrs-contactgroup/notae-praehistoricae/notae-praehistoricae-30-2010/

Heim, J. 1971, Datation par la palynologie d'un fond de fossé de la civilisation Michelsberg à Petit-Spiennes. In: Fossés néolithiques à Spiennes. Premier rapport (Hubert F., Ed), Archaeologia Belgica Vol. 136, Service national des Fouilles, Brussels: p. 62-66. (in French) ("Palynological dating of a ditch bottom of the Michelsberg culture")

Hubert, F. 1969, Fouilles au site minier néolithique de Spiennes. Campagne de 1965, Archaeologia Belgica Vol. 111, Service national des Fouilles, Brussels: 48 p. 15 pl. (in French) ("Excavation at the Neolithic mining site of Spiennes. 1965 campaign”)

Hubert, F. 1971, Fossés néolithiques à Spiennes. Premier rapport. Annexe de J. Heim, Archaeologia Belgica Vol. 136, Service national des Fouilles, Brussels: 68 p., 35 pl. (in French) ("Neolithic ditches in Spiennes. First Report")

Hubert, F. 1976a, Une nouvelle zone minière à Spiennes, Archaeologia Belgica Conspectus, MCMLXXV (Service national des Fouilles, Brussels), 186: 12-15. (in French) (“A new mining zone in Spiennes”)

Hubert, F. 1976b, Puits de mines à la tranchée du chemin de fer à Spiennes. Archaeologia Belgica Conspectus, MCMLXXV (Service national des Fouilles, Brussels), 186: 9-11. (in French) ("Mining shafts in the railway trench at Spiennes")

Hubert, F. 1978, Une minière néolithique à silex au Camp-à-Cayaux de Spiennes. Archaeologia Belgica Vol. 210, Service national des Fouilles, Brussels: 42 p. (in French) (“A Neolithic flint mine at Camp-à-Cayaux in Spiennes”)

URL: http://www.minesdespiennes.org/blog/wp-content/uploads/2013/02/Hubert1978_AB-210.pdf

Hubert, F. 1982, L’habitat néolithique dans la région de Nivelles. Annales de la Société d'Archéologie, d'Histoire et de Folklore de Nivelles et du Brabant wallon, 24: 9-36. (in French) ("Neolithic settlement in the Nivelles area") 
Hubert, F. 1983, Nouvelles fouilles aux minières néolithiques du Camp-à-Cayaux de Spiennes (Hainaut). Notae Praehistoricae, 3: 75-78. (in French) ("New excavations in the Neolithic mines of Camp-à-Cayaux in Spiennes (Hainaut)")

URL: http://www.naturalsciences.be/mars/groups/fnrs-contact-group/notaepraehistoricae/notae-praehistoricae/Hubert1983

Hubert, F. 1990, Essai de restitution de la technique de foudroyage du silex dans une minière néolithique de Spiennes. In: Le silex de sa genèse à l'outil. Actes du Vème Colloque international sur le silex, Bordeaux, 17 septembre - 2 octobre 1987 (Seronie-Vivien, M.R. \& Lenoir, M., Eds), Cahiers du quaternaire 17(1), Centre national de la Recherche scientifique, Paris: p. 265-266. (in French) ("Reconstruction attempt of the flint 'cavein' technique in a Neolithic flint mine at Spiennes”)

Jadin, I., Collet H., Woodbury, M. \& Letor, A. 2008, Indices d'extraction néolithique à Obourg - Le Village. Notae Praehistoricae, 28: 93-96. (in French) (“Neolithic mining evidence at Obourg - Le Village")

URL: http://www.naturalsciences.be/mars/groups/fnrs-contact-group/notaepraehistoricae/notae-praehistoricae-28-2008

Ladouce, S. 2002, Site archéologique de Petit-Spiennes: Lever souterrain. Travail de Fin d’Etudes. Haute école de la Communauté française du Hainaut, Institut supérieur industriel de la Communauté française, Mons, 150 p. (in French) ("Petit-Spiennes archaeological site: Underground mapping”)

Lavachery, P., Collet, H., Toussaint, M. \& Woodbury, M. 2015, Mons/Spiennes: Fouille du puits d'extraction ST 6 à «Petit-Spiennes». Chronique de l'Archéologie wallonne, 23: 88-90. (in French) (“Mons/Spiennes: ST6 shaft excavation at Petit-Spiennes”)

URL: http://www.minesdespiennes.org/blog/wpcontent/uploads/2015/12/Lavachery_etal_2015.pdf

Letocart, L. 1970, Un gisement du Paléolithique final à Obourg «Saint Macaire» (Hainaut). Frühe Menschheit und Umwelt, Archäologie Beitrage 1: 352-361. (in French) (“A Final Palaeolithic site at Obourg "Saint Macaire” (Hainaut)")

de Loë, A. \& de Munck, E. 1891, Notice sur des fouilles pratiquées récemment sur l'emplacement du vaste atelier néolithique de Spiennes (Hainaut). In: Congrès international d'Anthropologie et d'Archéologie préhistoriques. Compte-rendu de la dixième session, Ernest Leroux éditeur, Paris: p. 569-602, pl. VIII-XIX. (in French) ("Note on the recent excavations conducted on the vast flint workshop of Spiennes (Hainaut)")

Mercer, R.J. 1972, Grimes Graves, Norfolk. Excavations 1971-1972 Vol. I. Department of Environment, Archaeological Reports Vol. 11, Her Majesty’s Stationary Office, London, 122 p.

Miller, R., Haesaerts, P. \& Otte, M. 2004, L'atelier de taille aurignacien de Maisières-Canal (Belgique). Eraul 110, Service de Préhistoire de l’Université de Liège, Liège, 136 p. (in French) ("The Aurignacian knapping workshop of Maisières-Canal (Belgium)”) 
Di Modica, K. 2011, La documentation du Paléolithique moyen en Belgique aujourd'hui, état de la question. Bulletin de la Société royale belge d'Etudes géologiques et archéologiques «Les Chercheurs de la Wallonie» (asbl). (Le Paléolithique moyen en Belgique. Mélanges Marguerite Ulrix-Closset. Toussaint, M., Di Modica, K. \& Pirson, S., Eds), 4(special issue), Eraul 128: 75-104. (in French) ("The recent documentation on the Middle Palaeolithic in Belgium: A status report”)

URL: https://www.researchgate.net/publication/272504247

Moreau, L., Hauzeur, A. \& Jadin, I. 2013, La gestion des ressources lithiques dans l'ensemble gravettien de Maisières-Canal (Bassin de Mons, Hainaut, B). Nouvelles perspectives. Notae Prehistoricae, 33: 105-126. (in French) ("Lithic resources management in the Gravettian assemblage of Maisières-Canal (Mons basin, Hainaut, B). New insights”) URL: http://www.naturalsciences.be/mars/groups/fnrs-contact-group/notaepraehistoricae/NP33-2013

Pétrequin, A.-M. \& Pétrequin, P. 2000, Ecologie d'un outil. La hache de pierre en Irian Jaya (Indonésie). CRA Monographies 12. CNRS éditions, Paris, 464 p. (in French) ("Ecology of a tool. The stone axe in Irian Jaya (Indonesia)")

Pirson, S. \& Di Modica, K. 2011, Position chronostratigraphique des productions lithiques du Paléolithique ancien en Belgique: Un état de la question. Bulletin de la Société royale belge d'Etudes géologiques et archéolgiques «Les Chercheurs de la Wallonie». (Le Paléolithique moyen en Belgique. Mélanges Marguerite Ulrix-Closset (Toussaint, M., Di Modica, K. \& Pirson, S., Eds), 4(special issue), Eraul 128: p. 105-148. (in French) ("Chronostratigraphical position of Early Paleolithic lithic productions in Belgium”) URL: https://www.researchgate.net/publication/272504426

Reimer, P.J., Bard, E., Bayliss, A., Beck, J.W., Blackwell, P.G., Ramsey, C.B., Buck, C.E., Cheng, H., Edwards, R.L., Friedrich, M., Grootes, P.M., Guilderson, T.P., Haflidason, H., Hajdas, I., Hatté, C., Heaton, T.J., Hoffmann, D.L., Hogg, A.G., Hughen, K.A., Kaiser, K.F., Kromer, B., Manning, S.W., Niu, M., Reimer, R.W., Richards, D.A., Scott, E.M., Southon, J.R., Staff, R.A., Turney, C.S.M. \& van der Plicht, J. 2013, IntCal13 and Marine13 Radiocarbon Age Calibration Curves 0-50,000 Years cal BP. Radiocarbon, 55(4): 1869-1887. doi:10.2458/azu_js_rc.55.16947

Robaszynski, F. \& Christensen, W.K. 1989, The upper Campanian-Lower Maastrichtian chalks of the Mons basin, Belgium: A preliminary study of belemnites and foraminifera in the Harmignies and Ciply areas. Geologie en Mijnbouw, 68: 391-408.

URL: http://www.vliz.be/en/imis?module=ref\&refid=249769

Robaszynski, F., Dhondt, A.V. \& Jagt, J.W.M. 2001, Cretaceous lithostratigraphic units (Belgium). Geologica Belgica (Guide to a revised lithostratigraphic scale of Belgium, Bultynck, P. \& Dejonghe, L., Eds), 4: 121-134. URL: http://popups.ulg.ac.be/13748505/index.php?id=1951

Roth, G. 2008, Geben und Nehmen. Eine wirtschaftshistorische Studie zum neolitischen Hornsteinbergbau von Abensberg-Arnhofen, Kr. Kelheim (Niederbayern). Dissertation zur Erlangung des Doktorgrades im Fach Ur- und Frügeschichte an der Philosophischen Fakultät der Universität zu Köln, 333 p. (in German) (“To give and to take. A socioeconomic study of Abensberg-Arnhofen Neolithic flint mine, District Kelheim (Niederbayern)”) URL: http://kups.ub.uni-koeln.de/4176/ 
Tarantini, M. \& Galiberti, A. 2011, Le miniere di selce del Gargano VI-III millennio a.C. Alle origini della storia mineraria europea. All’Insegna del Giglio, Firenze, 277 p. (in Italian) ("The Gargano flint mines of the $6^{\text {th }}-3^{\text {rd }}$ millennium. At the origin of the European mining history”)

Topping, P. 2011, The evidence for the seasonal use of the English flint mines. In: Proceedings of the 2nd International Conference of the UISPP Commission on Flint mining in Pre- and Protohistoric Times Madrid, 14th-17th October 2009 (Capote M., Consuegra S., Díaz-del-Río P., Terradas X. Eds), British Archaeological Reports International Series Vol. 2260, Archaeopress, Oxford: p. 35-43.

Verheyleweghen, J. 1953, Découverte sur le territoire de Spiennes d'une phase d'occupation des hommes de Michelsberg antérieure à celle du plateau du "Camp-à-Cayaux" (Compte-rendu des fouilles entreprises en 1953). Bulletin de la Société royale belge d'Anthropologie et de Préhistoire, 64: 141-162. (in french) ("Discovery in Spiennes of a Michelsberg occupation antedating the one of Camp-à-Cayaux")

Verheyleweghen, J. 1958, Découverte de deux lampes néolithiques au “Camp-à-Cayaux” à Spiennes, avec le problème d'éclairage de la minière (Prolégomènes à Spiennes néolithique). Bulletin de la Société royale belge d'Anthropologie et de Préhistoire, 69: 233-244. (in French) ("Discovery of two Neolithic lamps at camp-à-Cayaux in Spiennes, with the issue of the lighting in the mines (Prolegomena to Spiennes in the Neolithic period)")

Vermeersch, P.M., Vynckier, G. \& Walter, R. 1990, Thieusies Ferme de l'Hosté, site Michelsberg. II Le matériel lithique. Studia Praehistorica Belgica, 6. KULeuven, Leuven, 70 p. (in French) (“Thieusies Ferme de l’Hosté, Michelsberg settlement. II The lithic material”) URL: https://www.academia.edu/6793699/

Verstraelen, N. 2015, Camp-à-Cayaux et Petit-Spiennes. Conservation. Rapport annuel 2014. Date: 2014. Unpublished report for the Service public de Wallonie, on file. Liège, 84 p. (in French) (“Camp-à-Cayaux and Petit-Spiennes. Conservation. Annual report”) 